\title{
The U.S. Currency System: A Historical Perspective
}

\section{$\mathbf{T}$} regular part of our daily lives and a basic feature of our economic system. The importance of currency derives both from its obvious role in daily transactions and from the somewhat more subtle role of the currency system as the basis for our monetary and financial systems. The currency system is so fundamental to economic activity that we tend to give it little thought. Few of us would have an easy time imagining what alternative systems might belike or why they might be desirable. Indeed, it seems likely that most of us, if pressed, would offer the opinion that the present currency system is the only one that is feasible-or at least, the only one that is desirable.

This article has three purposes. The first is to define the term "currency" and explain the special importance of currency and the currency system to our economy. The second is to describe the U.S. currency system-the system that governs the forms, lises and roles of currency in the modern United States. This description will be preceded by a catalog of the forms currency has taken at various points in the past, so that the modern U.S. system emerges as a set of selections from a menu of choices provided by history. This procedure is intended to suggest that alternative menu selections were possible-that the currency system which actually evolved in the Lnited States is not the only one that could have evolved. The anticle's third and most ambitious purpose is to present a brief but comprehensive account of the historical

1U.S. monetary history from the end of the Civil War through modern times has been chronicled quite extensively, notably by Friedman and Schwartz (1963). In addition, most of the key development of the U.S. currency system. This account focuses on the period before and during the Civil War. ${ }^{1}$ Its primary goal is to provide the reader with historical context that may improve his understanding of the modern currency system.

The historical account has a second purpose, however. The development of the U.S. currency system is often characterized as a process of slow but steady advancement: older institutions and practices, having failed to meet the demands of their times, were replaced by more efficient successors. This "gradual progress" characterization implies that the modern currency system meets the needs of our economy more efficiently than could any of the alternatives suggested by history. The historical account is intended to help determine whether this characterization is valid, and $w$ hether relative efficiency conclusions should be based on it.

\section{WHAT IS CURPPENCV?}

One approach to defining curreney is to contrast it with something whose definition is closely related, but more faniliar: money, Most people have been exposed at some point to an economist's definition of money; it usually reads something like "things that serve as media of exchange" of "things that function as means of payment." While all currency is money, all money is not currency. Currency can be defined as money which circu-

decisions that determined the basic form of the U.S. currency system were arguably made before 1865 . 
lates, or passes from hand to hand. "Circulation" was once commonly used as a synonym for currency.)

Formally, a type of money can be said to circulate if it usually passes in exchange from one person to another without third-party verification. One easy way to illustrate the difference between circulating and non-circulating money is to contrast dollar bills, which circulate, with checks, which do not. ${ }^{2}$ A dollar bill may pass from one person to another many times in different transactions. 'The only people involved in each transaction are the buyer and seller. Transactions using checks require more complex arrangements. It is unusual for a check, written by one person in payment to another, to be offered in payment to a third person. Instead, the second person usually deposits the check in a bank account. His bank and the first person's bank then conduct a "clearing" transaction which, if successfully completed, validates the payment. ${ }^{3}$

In the modern United States, only dollar bills and coins, issued by agencies of the federal government, fit the definition of currency. Earlier in our history (and that of many other nations) the number of alternative types of currency was larger, and included items issued by private organizations. The next section presents a brief catalog of some of the varieties of currency that have existed in the past.

\section{WHAT FORMS CAN CURPENCW TAKE?}

\section{Commodity Currency}

The earliest forms of currency were commodi ties (widely traded goods). In colonial America, for

2Strictly speaking, economists think of the accounts against which checks are drawn (the demand deposits) as money, rather than the checks themselves.

3Typically, a person who is offered a newly written check in payment (the second party) will ask the check-writer (the first party) to present identification and will record information from the identification presented. The second party will deposit the check in his bank account. His bank will "clear" the check by sending it to the bank against which it is drawn and demanding payment in cash. The two banks are the "thizd parties" which are actually involved in most transactions using checks. The clearing transaction is necessary to verify that the check is drawn on an account that contains sufficient funds. If the check "bounces," it has falled the verification test. The amount of the check will not be credited to the second party's account, and he will use the intormation from the check-writer's ID to pursue him for some alternative form of payment. [The reason the second party will rarely try to pass the check along to a third party is that the third party is unilikely to accept it. (If you doubt this, try passing such a "third-party check" at your local grocery store.) A third party example, commodities such as wampum (colored beads), tobacco, wheat and rice were used as currency at different places and times. ${ }^{4}$ Gold and silver, the "precious metals," had attractive properties - portability, malleability and durability-which ultimately made them the currencies of choice in most early economies.

\section{Coin Currency}

As the volume of transactions involving gold and silver increased, people began to divide these metals into pieces of readily recognizable size and shape, called coins. The earliest coin-producing facilities (mints) seem to have been privately oper. ated. ${ }^{5}$ In most countries, however, the government eventually took over coin production.

The rationale behind the government takeover may well have included the belief that government-issued coins would be more uniform, and more reliable, than their privately issued counterparts. Early governments, however, could have resolved problems of diversity and fraud by regulating private mints and inspecting private coins, in essentially the same way that governments have long regulated and inspected other industries. ${ }^{6}$ A more compelling reason for government coin monopolies, however, was the desire to earn revenue from seigniorage-from periodically shortweighting or debasing the currency. ${ }^{7}$ Unless a government had a coinage monopoly, its attempts to earn substantial revenues from seigniorage would have been frustrated as the public abandoned its coins in favor of those minted by its private competitors.

The prevalence of government currency monopolies gave rise to the twin concepts of a typically has no easy way of obtaining reliable identification from the (absent) first party.]

4 For an extended discussion of the role of commodity moneyin the cotonies, see Nettels (1934), chapter VIII.

sFeavearyear (1963) describes early English cumency as follows: "At the beginning of the eighth century the currency consisted of smail silver coins varying in design according to the fancy of the individual moneyer." (p. 7)

sAdam Smith (1776/1937) points out that before coins evolved, govemments often stamped ingots of precious melal to certify their purity (pp. 24-25).

${ }^{7 A}$ coin is said to have been "shoriweighted" if it is minted with less than its official metallic weight, but represented as having exactly that weight. A coin is said to have been "debased" if it is minted as a mixture of genuine monetary metal and common scrap metal, but represented as pure monetary metal. These fraudulent practices were sometimes practiced by private mints as well. For a discussion of government seigniorage motives, see Jimberlake (1991), pp. 3-5, 50-51. 
national currency and a national monetary unit. Typically, a government would define a basic monetary unit as a fixed quantity of gold or silver. It would then mint coins in denominations that were multiples or fractions of this unit and were scaled appropriately in size and weight.

Most nations had an extended period during which government-issued coins were the only form of currency. One problem with these purecoin currency systems was that they had difficulty handling transactions of widely differing scales. If, for example, coins were denominated so that a single coin of moderate weight could be used to purchase an inexpensive item (say, an apple), then the coins necessary to purchase an expensive item (say, a carriage) were necessarily quite heavy. One common way in which governments tried to solve this problem was by establishing bimetallic coinage systems. In these systems coins of low value contained a relatively inexpensive metal (typically silver), while larger-value coins were composed of a more expensive metal (typically gold). The two types of coins were referred to collectively as specie.

The U.S. experience with specie currency illustrates most of the concepts just described. The U.S. Constitution gave Congress the power to "coin money, and regulate the value thereof"-a provision which has been universally interpreted as prohibiting the states either from minting coins directly or from authorizing private parties to do so. ${ }^{8}$ Shortly after the Constitution was ratified, Congress enacted legislation that defined the basic monetary unit, the dollar, as either a fixed weight of gold or a (different) fixed weight of silver. The federal government then opened a mint that produced dollar coins in accordance with these definitions. The mint also produced silver "quarters" containing one-fourth the amount of silver in a silver dollar, five-dollar gold pieces containing five times the amount of gold in a gold dollar, and so on. ${ }^{3}$ The U.S. Mint continued to produce full-bodied gold coins until the early 1930s, and full-bodied silver coins until the mid-1960s. (A full-bodied coin con" tains a quantity of metal whose market value is equal to the face value of the coin.)
As the magnitude of economic activity increased, the weight of the gold coins necessary for a major purchase, or even the quantity that a relatively wealthy person might desire to have on hand, became unmanageably large. Coins also tended to wear away or have their edges clipped. After a few years, coins of the same denomination could be significantly different in size. ${ }^{10}$ These problems made coins increasingly unsatisfactory, even for relatively small-scale transactions.

\section{Bills of Exchange}

An obvious solution to the "weight problems" of the coin currency system was to find or create lightweight objects that, while not made of coins themselves, had known values in terms of coins. Objects like this already existed: they were promissory notes-contracts between borrowers and lenders calling for the repayment of fixed sums (in coin) at fixed future dates.

One special type of promissory note, the bill of exchange, was readily adapted for use as currency. Bills of exchange grew out of commercial transactions in which merchants would arrange to purchase goods from other merchants for delivery at fixed future dates (for example, in 90 days). Often the seller could not afford to produce and/or deliver the goods unless he received immediate payment, while the buyer was reluctant to pay for the goods before receiving delivery, One solution to this problem was an exchange of contracts. The seller would contract to deliver the goods at the date in question, while the buyer would contract to pay the purchase price at the delivery date. The latter contract took the form of a conventional promissory note.

This exchange of contracts may not seem to have addressed the seller's immediate problem: to obtain the currency needed to finance the production and/or transport of his goods. Suppose, however, that the seller, armed with his promissory note, sought to purchase materials from a supplier. He could then write out another eredit instrument-a bill of exchange--calling on the merchant who had issued the promissory note to pay the supplier the purchase price of the materials, plus an allowance for interest, in 90
פU.S. Constitution, Article I, Section 8

sSee Huntington and Mawhinney (1910), pp. 474.79. Gold doflar coins were not actualy mined until 1849 . See Garothers (1930), pp. 105, 109, and Huntington and Mawhinney (1910), pp. 508-09.
10 For a description of the clipping problem in pre-eighteenth century England, see Feavearyear (1963), pp. 5-6, and Macaulay (1877), volume V, pp. 85-93. 
days. This process was called drawing a bill; the original goods seller was called the drawer and the issuer of the promissory note the drawee. The drawee would accept (agree to cover) the bill as long as its value was less than that of the promissory note. He would indicate his acceptance by endorsing the bill."

By accepting the bill, the supplier was, in effect, lending the seller the value of the materials the latter had "purchased." The supplier, however, usually did not expect to hold the bill until it came due. Instead, he planned to pass it along to someone from whom he wished to purchase goods; this person might pass it along to someone else, and so on, until the bill matured. The last person in the chain would demand payment from the drawee. In between, the bill served as paper currency. ${ }^{12}$

Notice that drawing a bill was analogous to writing a check, with the drawee of the bill playing the same role as that of a bank on which a check is drawn. It seems to follow that bills of exchange should not have circulated, for precisely the same reasons that modern checks do not circulate. There was a basic difference between a bill of exchange and a modern personal check, however. Because no one would accept a bill unless it was endorsed by the relevant drawee, the question of "bad checks"-checks written by individuals with insufficient funds - did not arise. Stated differently, an accepted bill was purely a liability of the drawee; a person offered a bill in payment did not need to be concerned about the creditworthiness of the drawer. ${ }^{13}$

It is true that bills were occasionally dishonored by their drawees, just as modern banks occasionally fail. ${ }^{34}$ As long as the bills were drawn against well-known merchants with established reputations in commerce, however, failures were uncommon. Consequently a person who accepted a bill in payment could be reasonably confident that, if he did not have occasion to pass it along, he could redeem it when it came due. ${ }^{15}$

Although bills of exchange became an important adjunct to coin currency, a number of problems limited their usefulness. Since they were typically drawn in fairly large denominations (of the sort appropriate for trade between merchants), they were not well suited for small-scale transactions. And, as the volume of trade in a given region increased, it became less and less likely that a person proffered a bill would be familiar, either personally or by reputation, with the merchant against whom it was drawn. Consequently, dishonored bilss became a more serious problem, and people became hesitant to accept them in payment. A less fundamental, but still annoying, problem was that whenever a bill changed hands, interest had to be calculated and deducted from its face value. This fairly involved calculation required consideration of both the remaining term on the bill and the market rate of interest.

\section{Bark Notes}

The transactions problems with bills of exchange created opportunities for private entrepreneurs to profit by providing paper currency in more convenient forms. Suppose an enterprising merchant with a good reputation sold small bills of exchange in return for specie and used the proceeds to buy large bills with the same maturity dates. The proceeds of the large bills would then provide a fund out of which the small bills could be redeemed. Because small bills were much more convenient for exchange purposes than large bills, they were slightly more valuable, per dollar of face value, to their holders. ${ }^{16}$ As a result, small bills could be sold at smaller percentage discounts (lower interest rates) than large bills. It followed that the total purchase price of the large bills necessary to cover a given face value of small bills was smaller than the total sale price of the small bills. This difference in total prices represented the merchant's profits.

\footnotetext{
"See Clough and Cole (1941), pp. 77-78.

12 In England, bils of exchange played a prominent rote as means of payment during the seventeenth and eighteenth centuries; see Feavearyear (1963), pp. 160-62. In several English districts, they retained this role well into the nineteenth century; see Clapham (1944), II, pp. 90-91, 97-98, Viner (1937), p. 123, and Feavearyear (1963), p. 165.

13 It is worth noting that while it is usually difficult to negotiate a third-party check drawn on an individual's bank account, a check drawn on the account of a government agency or prominent local corporation may be easy to negotiate.
}

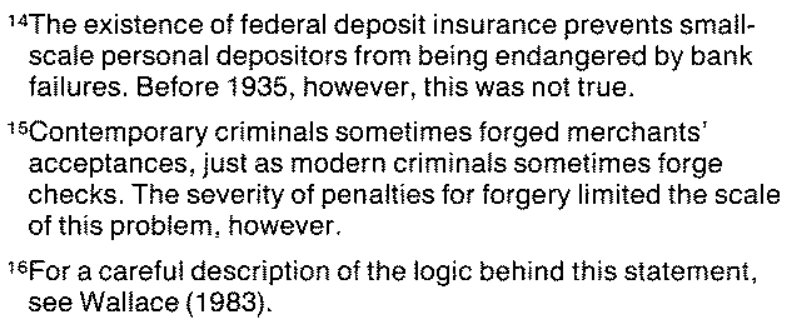

${ }^{14}$ The existence of federal deposit insurance prevents smallscale personal depositors from being endangered by bank failures. Before 1935, however, this was not true.

${ }^{15}$ Contemporary criminals sometimes forged merchants' acceptances, just as modern criminals sometimes forge checks. The severity of penalties for forgery limited the scale of this problem, however.

${ }^{16}$ For a careful description of the logic behind this statement, see Wallace (1983). 
The merchant had now become a banker, and the institution he operated a bank of issue-a financial intermediary whose liabilities consisted primarily of paper currency. ${ }^{17}$ The small bills came to be known as bank notes.

The merchant could increase his profits from note issue by reducing the risk that he would default on his notes. This would reduce the "risk premium" that small billholders demanded, and enable him to sell the bills at smaller discounts. One strategy for accomplishing this was to diversify his large bill portfolio as extensively as possible. Another was to provide, or to obtain from investors, some capital to act as a cushion against defaults on the large bills.

$A$ basic problem with the scheme just described was that the time and effort necessary to compute the appropriate discount on a bank note was usually large relative to the face value of the note. This reduced the usefulness of notes in transactions and discouraged people from purchasing them. ${ }^{18}$ One way to solve this problem was to issue notes with characteristics so appealing that their holders would be willing to forgo interest on them. How could this be accomplished?

Since we have assumed (perhaps too quickly) that proper diversification and capitalization made the risk on bank notes negligible, the need for interest on them arose purely out of their holders' time preference-their desire to be compensated for giving up their money (in this case, their specie currencyl for fixed periods. Suppose, however, that a merchant promised to redeem his notes on demand (at any time) instead of at a fixed future date. Since the purchaser of such notes could reclaim his specie whenever he chose, he would not be giving it up for any fixed period, and would have no reason to demand interest. The bills could then be sold at par (undiscounted).

How could a merchant make such a convertibility commitment credible? Clearly, he would need to hold back some of the (specie) proceeds of his note sales for use as reserves. These reserves would not have to be large, however, because as long as noteholders were confident that they could redeem their notes, there was no particular reason why they would do so. After all, the holders had bought the notes because they were more convenient for exchange purposes than specie.

Notice that there is some circularity in the argument just presented. Convertibility, it asserts, was necessary to prevent noteholders from demanding compensation for giving up their specie, which they had been holding for use as money. But these people had exchanged their specie for notes precisely because the notes were a more conven. ient form of money! This paradox makes it seem possible that convertibility is not really necessary; indeed, there are both historical and theoretical reasons for suspecting that it may not be. In practice, however, the vast majority of private banks of issue have attached convertibility commitments to their notes. ${ }^{.9}$ The Bank of England, for example, began circulating convertible notes shortly after it received a royal charter in 1695 . These notes became the principal paper currency of the relatively developed region surrounding London (the "Metropolis")." zo

\section{Government Paper Currency}

Governments eventually acquired a role in the paper currency system by regulating the issuance of private paper currency, and/or by issuing paper currency directly. The motives for this decision were essentially the same as those which drove governments to acquire a monopoly over coinage: some combination of a desire to improve efficiency by facilitating the development of uniform and reliable paper money, and a desire to earn revenue by regulating or replacing the private banking system. This revenue has been earned in a variety of ways. In some cases, governments have earned substantial sums by granting private institutions the right to issue paper currency in return for some kind of financial consideration. (See, for example, the discussion of the establishment of the Bank of England which appears below. In other cases, revenue has been earned through direct currency seigniorage, in which the government issues paper currency to purchase goods and services, or through indirect seig-

liquidation. Incomplete information problems make it impossible for these agents to detect fraud without a liquidation. While this model is not reasonable in every historical context, it represents a first step toward explaining the prevalence of convertibility.

${ }^{20}$ For the early history of the Bank of England, see Clapham (1944), volume l. 
niorage, in which the government issues paper currency to purchase and retire its own bonds.

Government paper currency can take a variety of forms. The earliest form of government paper currency - and until quite recently, the most common form-was representative currency. A government currency is said to be "representative" if it is issued under a convertibility commitment; that is, a government promise to redeem the currency in specie, at par and on demand. Representative currencies are the government-issued analogues to private, convertible bank notes. $W$ hile they have usually been issued by government-organized "central banks," they have sometimes been issued directly by the government. The United States, for instance, had directly issued representative currency during 1879-1913 the U.S. notes, or "greenbacks," which were issued by the Treasury) and representative currency issued by a central bank during 1914-1933 the Federal Reserve notes, which were issued by the Federal Reserve Banks).21

Governments have also issued currency that is not convertible into specie, or anything else. This type of currency is often referred to as fiat currency. ${ }^{22}$ During the Civil War, both the Union and the Confederacy issued fiat currency to finance part of their military purchases. The Union currency was the greenback mentioned above. Modern U.S. currency is also fiat in nature. Federal Reserve notes (our dollar bills) have not been convertible for domestic holders since 1933; since 1971, they have not been convertible for any holders whatsoever. 'The Federal Reserve Banks issue most of these notes in purchase of U.S Treasury securities. ${ }^{23}$

\section{WHAT IS A CURRENCY SYSTEM?}

A nation's currency system can be defined as the set of laws, conventions and practices that determine the form and role of currency in the nation's economy. A complete description of a nation's curmency system would provide answers to questions like: "What things does the economy of this nation use as currency?", "What sorts of institutions (private and/or government) are permitted to issue currency under the nation's laws?" "What role (if any) does the nation's government play in defining the economy's currency unit, or in pre. serving its value?", and "What is the nature of the relationship between the nation's currency system and its monetary and financial systems?"

\section{HOW DOES THE U.S. CURRENCY SYSTEM WORK?}

This section will provide a brief summary of the history and legal framework of the U.S. currency system. It will focus on a pair of legal restrictions that play a critical role in shaping the system. These restrictions would be prime candidates for revision or repeal if the system were to be reformed or deregulated.

As previously noted, the U.S. Constitution gave Congress exclusive power to define a national monetary unit and produce coined currency. In addition, the states were explicitly prohibited from issuing paper currency directly. ${ }^{24}$ The
21The greenbacks were first issued in 1863 , but were not convertible until 1879 . Federal Reserve notes were convertible for domestic holders from the establishment of the Federal Reserve System in 1914 until March 1933. They remained convertible for certain foreign holders until 1971.

22A distinction is sometimes made between inconvertible government currencies that are issued in purchase of assets (and so form the liabilities side of a "balanced" balance sheet), and currencies which are issued in purchase of goods and/or services. Currencies of the former type are referred to as fiduciary. Many economists believe that currencies derive much of their value from the assets which back them. Descriptions of this view appear in Smith (1985b) and Russell (1989a). It suggests that fiduciary currencies may be less likely to decline in value (that is, to depreciate) than fiat currencies

${ }^{23}$ Strictly speaking, the Federal Reserve System pays for the Treasury securities it purchases by issuing claims on the Federal Reserve Banks. These claims can be redeemed in currency-Federal Reserve notes - which can be held by the general public as cash balances, or by commercial banks as reserves. Alternatively, the claims can be converted into demand deposits at the Federal Reserve Banks, which can also be used by commercial banks as reserves. The decision concerning how the claims are divided between these competing uses is made by the private sector.

At present, currency held by the public, of as reserves, accounts for about 85 percent of total claims on the Federal Reserve Banks, while U.S. Treasury securties account for about 75 percent of their total assets. In addition, the economic implications of the scheme for paying for these securities just described are identical to those of an alternative scheme under which the System paid for Treasury securities with newly issued Federal Reserve notes, and the private sector decided how much of this currency to retain and how much to deposit with the Reserve Banks.

The Federal Reserve Act prohibits the System from purchasing newly issued Treasury securities-an action that would amount to issuing currency (and/or Reserve Bank deposits) to finance government purchases. [See the definition of "indirect currency seigniorage" presented earlier in this section.]

${ }^{24}$ Article I, Section 10 of the U.S. Constitution denies the states the power to "emit Bils of Credit;" this was almost universally understood to prohibit them from issuing their own currency. 
Constitution was silent, however, on two ques. tions that ultimately became controversial: Does the federal government have the right to issue paper currency? Do either the federal government or the states have the right to authorize private institutions to issue paper currency-do they have the right, that is, to grant charters to private banks?

Shortly after the Constitution was ratified, the states began to charter private banks of issue. ${ }^{25}$ In 1791, and again in 1816, the federal government chartered a single private bank - the Bank of the United States. For the next three-quarters of a century, the bulk of the paper currency that circulated in the U.S. was issued by state banks; virtually all of the remainder was issued by the United States Bank. The rights of the federal government and the states to charter private banks were eventually affirmed (in separate decisions) by the U.S. Supreme Court. ${ }^{26}$

In 1865 , Congress imposed a tax on note issue by state banks that was high enough to make the activity unprofitable. This action, which came one year after Congress had established a system of federally chartered banks of issue called the National Banking System, was evidently intended to put an end to state banking. ${ }^{27}$ Another wartime innovation was the issuance, beginning in 1862, of "greenbacks." For the next 50 years, the U.S. stock of paper currency consisted almost entirely of national bank notes and greenbacks. ${ }^{2 s}$

The Civil War produced a dramatic expansion of the federal government's role in, and powers over, the U.S. monetary system. In the years immediately following the war, the right of the federal government to play this role, and to exercise these expanded powers, $w$ as affirmed in a series of
Supreme Court decisions. The war converted a political system in which the monetary powers of federal government were sharply circumscribed into one in which they were virtually unlimited.

Almost half a century later, the federal government's monetary powers were wielded in dramatic fashion when Congress passed the Federal Reserve Act of 1913. This legislation established 12 "Federal Reserve Banks" that collectively constituted a "central bank" for the United States. ${ }^{29}$ The Reserve Banks issued a new form of representative paper currency called "Federal Reserve notes." These notes became the basis for the U.S. currency system.

During the first two decades following the passage of the Federal Reserve Act, the national banks retained the right to issue limited quantities of notes. In 1935, however, the national banks' issue rights expired; Congress declined to renew them, and made provisions for the gradual retirement of all national bank notes still outstanding. ${ }^{30}$ Since 1935, the Federal Reserve Banks have been the only U.S. organizations authorized to issue paper currency on a regular basis. ${ }^{31}$

The result of this historical process can be summarized as the first of two basic legal restrictions which govern the U.S. currency system: the federal government has a legal monopoly over the issuance of currency, whether in coin or paper form.

The second basic legal restriction involves the relationship between currency, which is now exclusively federally issued, and "money" of other sorts, which continues to be provided by the private sector. Privately issued money is required to be convertible (redeemable at par and on

ment currency of other sorts. See Friedman and Schwartz (1963). pp. 124-34, and Timberlake (1978), chapter 10.

${ }^{29}$ The text of the act appears in the Annual Report of the Federal Reserve System for 1914.

30See Friedman and Schwartz (1963), p. 442.

31 In principle, Congress retains the right to authorize the Treasury to issue paper currency directly. It has declined to do so, however, since the establishment of the Federal Reserve System. 
demand in government currency. ${ }^{32}$ In practice, privately issued money consists of deposits at commercial banks and thrift institutions that are potentially convenient as media of exchange-i.e, that are readily transferable (checkable) and available in small denominations. The government requires that these deposits be convertible, and they are referred to as "demand deposits."

If demand deposits are to be convertible into government currency, they must be denominated in the same units, and have the same market value per unit, as government currency. Consequently, the convertibility restriction, combined with the government's currency monopoly, imposes a common denominational and value standard on all U.S. money. The denominational standard is of course the "dollar," the basic unit of government currency; the value standard is the purchasing power of a dollar (or any fixed number of dollars) of this currency.

It is worth noting that governments usually attempt to enhance the acceptability of their currency by making it legal tender. Legal tender laws either require or strongly encourage people to accept government currency in payment of nominal debts-debts denominated in national currency units. In the United States, both coins minted by the Treasury and Federal Reserve notes are legal tender.

\section{HOW DID THE MODERN U.S. CURRENCY SYSTEM DEVELOP?}

Science has been slow to admit the different explanatory world of history into its domain-and our interpretations have been impoverished by this omission. Science has also tended to denigrate history, when forced to a confrontation, by regarding any invocation of contingency as less elegant or less meaningful than explanations based directly on timeless "laws of nature."

-5tephen Jay Gould (1989).

\section{English Origins}

Synopsis: The origins of the modern U.S. currency system can be traced in large part to Eng. land. Many important features of the U.S. currency system were based on English models. The early history of paper currency in England was dominated by the government's need for specie revenues to finance its foreign wars. This need caused the government to establish two principles-Bank of England monopoly, and strict specie convertibility -as the basis for England's system of paper currency. These principles had a profound effect on the evolution of paper currency and banking in the United Kingdom, and later in the United States.

In England, the notion of organized note issue seems to have arisen during the latter part of the seventeenth century. At the time, England had had a government-monopoly coin currency system for several centuries, and had begun to develop a paper currency system based on bills of exchange. ${ }^{33}$ During the last decade of the seventeenth century several groups of entrepreneurs recognized an opportunity to profit by providing a more convenient paper currency. Each of these groups sought royal charters for banks of issue.

Horsefield (1960) singles out four groups for special study, One of them, led by William Paterson, proposed a bank which would lend convertible notes on commercial security. The new bank was called the Bank of England. It received a charter in 1695 , and has operated continuously since; it is now the central bank of the United Kingdom. ${ }^{34}$

Three other groups, led by Hugh Chamberlen, John Briscoe, and John Asgill and Nicholas Barbon, respectively, proposed "land banks" which would lend inconvertible notes on the security of land and other real property. The land banks of Briscoe and Asgill-Barbon actually operated for a short time during 1695-96. In the latter year, they were consolidated pursuant to a scheme to secure a royal charter by raising $£ 2,000,000$ in specie to be lent to the British government, which was des-

charters issued during the late nineteenth century, under the National Banking Act, also included convertibitity requitements.

${ }^{33}$ For a description of early English monetary history, see Feavearyear (1963), chapters 1.IV.

34The defintlive history of the Bank of England has been written by Sir John Clapham (1944, two volumes). converibitity requirement was fargely implicit. Early in the nineteenth century, however, states began to pass legislation which explicitly imposed convertibitity on the banks-or, alternatively, to include convertibility requirements in bank charters. The federally chartered United States Banks had convertibility requirements in their charters. Convertibility requirements were standard fealures of state charters issued under the "Free Banking" laws of 1836-63. The federal 
perate for funds. The charter of this "National Land Bank" required that it raise half of the specie loan prior to beginning operation. When it proved unable to do this, the charter lapsed and the scheme fell apart. ${ }^{35}$

The fear that a public accustomed to coin currency would not accept inconvertible notes certainly played a role in the collapse of the $\mathrm{Na}$ tional Land Bank and other land bank schemes. Nevertheless, even Horsefield (1960), who is generally unsympathetic to the concept of land banking, points out that "the major cause of these events was an accident of time." 36 The Bank of England, which had obtained its charter by means of a similar commitment to provide specie, had drained the capital market of funds. This problem was exacerbated by the onset of a commercial crisis, which forced the Bank of England to suspend specie convertibility of its notes. ${ }^{37}$

In 1697 the Bank of England obtained, in return for a further extension of credit to the government, a formal commitment that Parliament would authorize no other banks so long as the Bank existed. Its urgent desire for this commitment suggests that it continued to regard land banking as a viable competitive threat. Clapham (1944) writes that "the General Court the directors of the Bank of England] wanted no more Land Banks." 38 In 1708, in return for further loan commitments, the monopoly grant was "reenacted and made more precise." Parliament explicitly prohibited any firm consisting of more than six partners from issuing notes in England. ${ }^{\text {* }}$ Thereafter English note issue was dominated by the Bank of England. The small "country banks" operated in

${ }^{35}$ See Horsefield (1960), chapters 14-16, and Clapham (1944), volume l, pp. 33-34.

36Horsefield (1960), p. 246.

37lbid., pp. $246 * 47$.

${ }^{38}$ Clapham (1944), vol. 1, p. 47.

${ }^{39}$ See Clapham (1944), p. 65, and Feavearyear (1963), pp. 167-68.

40During 1797-1821 (the era of the Napoleonic Wars), the Bank of England suspended specie payments. Although its notes were not officially legal tender, they became so operationally. Specie virtually disappeared from circulation, most payments were made in Bank of England notes, and other English banks redeemed their notes in Bank of England notes. See Feavearyear (1963), pp. 182.85, and Viner (1937), p. 154.

4Macaulay (1877) provides a colorful and iluminating paragraph describing this relationship (IV, pp. 551-2).

${ }_{42}$ Clapham (1944), describing the Bank's first summer, observes that " what the government--mike the Bank-most its shadow, and evolved along strictly convertible lines. ${ }^{40}$

The development of the British currency sys* tem can be properly understood only in the context of the symbiotic relationship between the British government and the Bank of England ${ }^{41}$ The Bank regarded its paper currency monopoly as critical to its profitability, and was willing to make large financial concessions to the British government in order to protect and extend it. The British government, on the other hand, was willing to grant the Bank a monopoly because it needed the Bank's financial assistance-in particular, to help it obtain specie to finance foreign wars. ${ }^{42}$ Under the circum. stances, it was profoundly in the interest of both parties for government liabilities to be identified as closely as possible with Bank liabilities, and for Bank liabilities to be identified as closely as possible with specie. ${ }^{43}$ The simplest and most certain way to achieve this was for the Bank to lend extensively to the government and make its notes strictly convertible. ${ }^{44}$

In Scotland the situation was quite different. The convertible, commercial Bank of Scotland was chartered by the Scottish Parliament in 1695. This bank, unlike the Bank of England, was statutorily uninvolved in government finance. It was granted a 21-year note issue monopoly (which was not renewed). In 1705, both Hugh Chamberlen, who had now moved to Scotland, and John Law, who was later to achieve monetary infamy in France, proposed land banks for Scotland. Both proposals were rejected because they involved notes that were legal tender-a status Parliament was unwilling

wanted in the summer of 1696 was not a circulation of notes but cash, hard cash for the Army in Flanders' (vol. 1, p. 39).

${ }^{43}$ Clapham (1944) points out that under the Act of 1697, which formalized the Bark's monopoly, "forgery of the Bank's notes was to be punished with death, the penalty for clipping or coining the King's money. Bank notes were not yet the King's money, but they were getting near to it." (vol. 1, p. 50). In October of 1698 , he writes, the Englist Treasury agreed to " receive such bills of the Bank of England commonly called Bank Bills ... provided the said bills are not at any discount." The time was getting nearer when the Bank would circulate the Exchequer Bils for the Treasury, cash them on demand, accept them as deposits, make generous advances on their security, and even pay a dividend on them." (vol. 1, p. 56; my emphasis). And in 1710 , just two years after it had acted to further strengthen the Bank's monopoly status, the British Parliament passed an Act " "for engaging and obliging the Bank of England ... to exchange all Exchequer bilis for ready money on demand." (vol. 1, P. 67).

4h Sartoni (1984) asserts that 'the Bank's contract with its customers to fedeem its notes at a fixed price in terms of gold 
to grant private liabilities. ${ }^{45}$ Apparently, the fallure of the English land bank schemes had created a belief that inconvertible notes would be accepted only if they were legal tender. As we shall see, this belief was also widespread in the American colonies...where expertence ultimately refuted it.

During the eighteenth and early nineteenth centuries, Scottish banking was considerably more competitive than English banking. The major banks fought bitter "note duels, presenting their competitors' notes for payment in an effort to drain their specie reserves and force them to retrench. One defensive response to these duels was the issuance by Scottish banks of notes which contained an "option clause" -a clause that granted them the right to defer" specie payments for a fixed period in return for legal interest. ${ }^{46}$

Experiments like the option clause might well have led to further departures from convertibility in Scotland, where both the public and the government were more comfortable with banks and paper currency than their counterparts in England. During the financially troubled years of the early 1760s, however, the option clause and other "irregular" Scottish banking practices attracted unfavorable attention in England (whose Parliament had absorbed that of Scot. land in 1707). In 1765 the British Parliament stepped in with an act prohibiting notes con" taining an option clause, or any other departures from strict convertibility."

\section{Colonial Origins}

Synopsis: The American colonies experimented with a variety of currency systems based on inconvertible notes issued by colonial governments. During the early eighteenth century the British government began to regulate these systems. British regulation forced some of the colonies to back their notes more carefully, and eventually prevented all the colonies from mak. ing their notes legal tender. By the end of the colonial period many of the colonies had developed successful and popular currency systems. These systems were based on inconvertible notes which were carefully backed, and were not legal tender.

Conditions in early colonial America differed from those in England even more profoundly than did conditions in Scotland. In the colonies, the most pressing monetary problem was a specie shortage: the quantity of specie the colonists were able to retain seems to have been insufficient to meet their was a voluntary arrangement" (p. 15). He justifies this assertion by noting that the gold standard was not imposed by British law until 1821, more than a century after the Bank was founded. While this is certainly true, it is also true that until the early nimeteenth century much of British bank regulation was implicit rather than explicit. One illustrative example involves the monopoly status of the Bank of England. Most historians describe the Bank as having possessed a monopoly over joint-stock (corporate) banking in England. However, the Act of 1708 gave it a monopoly only over jointstock note issue. Nevertheless, none of the deposit banks in England attempted to organize in corporate form. Feavm earyear (1963) explains this by noting that, despite the lack of an explicit legal prohibition against joint-stock deposit banking, "there can be no question whatever that the intention was to give the Bank of England a monopoly of joint-stock banking, and that had any other institution of more than six partners attempted to carry on banking in England in any manner whatever at any time during the first half of the century it would have been suppressed" (pp. 167-68). Similarly, despite the lack of an explicit legal requirement that bank notes be convertible, there can be little question but that the intention was that they should be convertible, and that any attempts by the Bank of England, or any of the English country banks, to issue inconvertible or semiconvertible notes would have been suppressed-just as attempts of this sort by Scottish banks were suppressed (see below).

Santoni also asserts that the establishment of an official gold standard occurred as a result of 'the Bank's continuous prods to an unwilling government." He justifies this assertion by noting (1) that the deadlines set by Parliament for resump. tion were repeatedly postponed, and (2) that the Bank resumed paying specie for small notes in 1817 , and Parliament intervened in 1819 to prohibit it from doing so. However, Viner (1937), Clapham (1944), and Feavearyear all report that the government's primary goal in postponing resumption was to avoid embarrassing the Bank. [Viner writes that "the government continued to refuse to obligate the Bank of England to resume cash payments, and both government and Bank were obviously waiting for the course of events to disclose the auspicious occasion for resumption" (p. 172, my emphasis); Feavearyear notes that "the Government refused to allow the Bank's hand to be forced, and repeatedly extended the term of the Restriction Act" (p. 214).] These authors also describe the resumption atteript cited by Santoni as a failure, and the government prohibition as an attempt to prosect the Bank. Finally, both Clapham (1944, vol.2, p. 70) and Feavearyear (pp. 221-22) report that the Bank opposed the legislation which actually compelled it to resume specie payments.

${ }_{45}^{45}$ or a history of the early years of Scottish banking, see Checkland (1975) or White (1984). For a description of the Scottish land bank proposals and their fate, see Horsefield (1960), pp. 175-78, 215-16.

46The option clause has attracted a good deal of academic attention in recent years. See White (1984), pp. 25-30, $14 \uparrow-42$, Rockoff (1986) and Dowd (1988), for example.

47See Checkland (1975), pp. 118-21; White (1984), pp. 29-30. The legislation originally proposed ruled out the option clause only; it was later amended to rule out any notes not redeemable on demand. 
needs for a medium of exchange ${ }^{48}$ During the 1650s, the Massachusetts Bay Colony attempted to allay the shortage by operating its own mint (which produced the renowned "Pine Tree Shillings"). The British government viewed this action as usurping a royal prerogative, however, and forced Massachusetts to close the mint ${ }^{49}$ The colonies also experimented with commodity currencies of different types; these included wampum (Indian beads), rice and tobacco. ${ }^{50}$

Despite the public's need for more convenient means of payment, the introduction of a new form of government paper currency was motivated in the first instance by the fiscal exigencies of a colonial government. In 1696, the Massachusetts legislature experienced great difficulty financing an expedition against the French in Canada. It decided to issue "bills of credit" in the form of paper currency to use to purchase supplies. These bills were neither convertible nor ultimately redeemable in specie; they could, however, be used to defray future tax liabilities. This financing expedient proved quite successful, and the colony used it repeatedly during the ensuing 50 years. Within a very few years, other colonies began to adopt the practice-first in New England, and later elsewhere. By 1730 of so, bills of credit had become the principal currency of the American colonies. ${ }^{51}$

The earliest colonial bills were issued, like these Massachusetts bills, in anticipation of future taxes. After a few years, however, certain colonies began experimenting with bills that were issued on loan. Typically the issuing colony would pass laws providing that relatively small sums in new bills could be lent to individ. uals who were able to provide land or other sorts of property as collateral. IOften these loans were mortgage loans and were intended in part to encourage the colonists to settle and improve land.) These "loan office" or "land bank" issues became increasingly popular during the first half of the eighteenth century. ${ }^{52}$

As previously indicated, the legislation authorizing the emission of tax anticipation or loan office bills was typically accompanied by legislation providing for their eventual retirementeither by imposing future taxes which the bills could be used to pay, or setting out the terms according to which the loans would be secured and repaid. The legislators clearly believed that it was these retirement commitments that conveyed value to the bills. ${ }^{33}$ Unfortunately, there were often great political and financial incentives for the colonies to violate these commitments by declining to levy or collect the future taxes, by declining to collect the loan payments, or by stretching out the period over which loans could be repaid. When these things happened, the bills would often depreciate in value relative to specie and goods. ${ }^{54}$ The extent of the depreciation was typically measured by the discount on paper currency relative to specie currency; that is, by the difference, in percent, between unity (one) and a fraction equal to a given quantity of specie currency divided by the quantity of paper currency it could be sold for in the open market. If it took 50 shillings in paper currency to purchase 40 shillings in specie currency, for instance, then the discount on paper currency was 20 percent. During the early decades of the eighteenth century, many colonial currencies experienced significant depreciation. In some cases, the depreciation was quite severe..$^{55}$

Currency depreciation became particularly controversial because most colonies gave their bills of credit the status of legal tender. Legal tender laws compelled creditors to accept bills at face value in payment of debts. If, for example, a loan agreement called for a repayment of 500 shillings at the end of five years, the lender could be forced to accept 500 shillings in bills of credit,
49For discussions of the specie shortage, see Nettels (1934), pp. 202-207, and Brock (1975), pp. 1-9.

49 See Felt (1839), Bullock (1900), Chapter III, Breckinridge (1903), pp. 55-56 and Nettels (1934), p. 276.

soNone of these experiments proved particularly satisfactory. For a description of colonial experiments with commodity currency see Netteis (1934), chapter VIII, and Brock (1975), pp. 9-16.

57For an encyclopedic account of colonial currency history prior to 1764 , see Brock (1975).

52For discussions of colonial land banking, see Davis (1900), Kemmerer (1939), Thayer (1953), Biilias (1959), Brock (1975) and Smith (1984), among others.
53Nettels (1934) writes that "In the opinton of the colonists, the principal factor affecting the specie value of their paper was the provision made for redeeming it from tax revenves" (pp. 257-58).

${ }_{54}$ For analyses of the fink between backing and depreciation, see Smith (1984, 1985a, 1985b) and Russell (1988).

${ }^{55}$ Data on the specie prices of the currencies of various different colonies are presented by Brock (1975) and Smith (1984, 1985a, 1985b), among others. 
even though he might prefer specie. The penalties for refusing to accept bills were relatively harsh: the creditor might forfeit the entire amount of the debt or, in some cases, a multiple thereof. 56

The original idea behind legal tender laws was to protect borrowers, and to reduce the frequency of lawsuits, by providing a method of repayment which was beyond legal challenge. ${ }^{57}$ When unexpected depreciation occured, however, legal tender laws tended to benefit debtors (by reducing the real value of their obligations) at creditors' expense. This made them popular with farmers and other debtors, and umpopular with creditor interests.

The creditor interests included a number of British merchants who did business with the colonies. Many of these merchants were wellconnected in Great Britain; their complaints, which were seconded by those of indigenous merchants and creditors, received sympathetic attention from the British colonial administration, and eventualy from the British Parliament. After 1730 , the colonial administration began to issue regulations eliminating or restricting the right of particular colonies to issue new bills or mote frequently) to make them legal tender. As the problem of depreciation worsened, however, Parlia ment considered comprehensive legislation. The Currency Act of 1751 deprived the New England colonies of the right to issue legal tender bills and greatly restricted their powers to issue paper cur. rency of any description. In 1764, a second Currency Act extended the legal tender prohibition to all the colonies. ${ }^{58}$
Many colonies responded to the legal tender prohibitions by issuing non-legal tender bills of credit. Although many contemporary analysts be. lieved that giving the bills legal tender status was essential to preserve their value, this does not seem to have been the case in practice. ${ }^{59}$ The non-tender bills remained quite stable in valuefar more stable, in many cases, than their legal tender predecessors. This was particularly strik. ing because many non-tender issues took the form of land banks-a mode of issue the British regarded as particularly prone to depreciation. ${ }^{60}$ During the decade prior to the Revolution, the colonies appeared to be moving toward a system of non-legal tender land bank currency. ${ }^{67}$

\section{Revolution and Reorganization}

Synopsis: The Revolution completely disrupted the evolution of the American currency system. The Continental Congress was forced to finance wartime expenditures by money creation-a policy which led to a virtual hyperinflation. 'The war, and the depression that followed it, produced financial problems for both state govemments and the general public. One symptom of these problems was large public and private debtsmany of which were held by the domestic propertied classes. This situation, combined with memories of the recent inflation, created fears among the members of these classes that popularly elected state governments would adopt monetary policies designed to partially repudiate these debts. Representatives of the propertied classes dominated the Constitutional convention. They moved
56 See Bullock (1900), p. 13†, Nettels, (1934), p.265, and Russell (1988), pp. 47-48.

57See Breckinridge (1903), p. 52, and Hurst (1973), p. 40. West (1978) stresses the role of colonial paper currency in providing a "means of settlement" "but does not mention legal tender laws explicitly.

58Even before the blanket legal tender prohibition, the British government had intervened to prevent particular colonies from making their currencies legal tender. lt also intervened to force some of the colonies to back their legal tender currencies more carefuly with future tax receipts, and to prevent others from issuing currency on loan. See Davis $(1900, \mathrm{vol}$. I and 1), Ferguson (1953), Ernst (1973), Brock (1975), Smith (1984,1985b) and Russell (1988).

For the history of the Currency Acts, see Davis (1900), Greene and Jellison (1961), Ernst (1973), Brock (1975), Smith (1985) and Russell (1988).

s9in 1767, Ben Franklin wrote that "On the whole, no method has hitherto been formed to establish a medium of trade, in lieu of money, equal, in all its advantages, to bills of credit, funded on sufficient taxes for discharging it, or on land secu. fity ... and in the mean time made a GENERAL LEGAL

TENDER." [Franklin (1971), p. 354; his emphasis.] Ferguson
(1953) writes that "The restraining act of 1764 ... prohibited legal tender laws and required that existing legal tender currencies be sunk at their expiration dates. Many colonies protested, in the belief that the legal tender feature was an essential prop to their currency. Experience was to show. however, that the restriction did not materially impair the workings of the currency system' (p. 177).

60For discusstons of the strong performance of nontender paper currency, see Enst (1973), Smith (1984b) and Russell (1988).

61See Ferguson (1953), pp. $177-180$. Inconvertible government currency which was not legal iender is of special historical interest because it was issued under circumstances that approximated relatively closely the cifcumstances under which inconvertible private currency might have been issued. This was especially true when, as was frequently the case, the currency was issued on loan rather than in anticipation of taxes. Russell (1988) argues that the success of government, non-legal-tender, inconvertible land banking before the Revolution provides indirect evidence that private inconvertible banking might have been feasible after the Revolution, had it been legally permitted. 
to prevent repudiation by prohibiting the states from issuing their own currency, or from making privately issued currency legal tender.

During the Revolutionary War, the Continental Congress was the American central government, and bore primary responsibility for conducting and coordinating the war effort. It also faced a critical financing problem: under the Articles of Confederation, it lacked the power to levy taxes. (Colonial opposition to British taxation had been one of the most important causes of the rebellion.) During the early stages of the Revolutionary War, the Congress attempted to subsist on voluntary contributions from the colonies. When this source of revenue proved insufficient, it began to issue bills of credit - the renowned "continentals" which were backed by little more than the pious hope that the states would eventually provide funds, or authorize tax levies, to retire them. The likelihood of such retirements became ever more distant as the quantity of continentals increased and the states supplemented them with their own currency issues. Both forms of paper currency began to depreciate-at first gradually, and later very rapidly. By the end of the war, they were virtually worthless. ${ }^{62}$

During the brief "critical period" between the end of the war (in 1783) and the ratification of the U.S. Constitution (in 1789), the newly independent states began to reorganize their finances and consider the problem of providing a paper currency. A number of states issued or seriously considered issuing bills of credit in anticipation of taxes or on loan-much in the manner of the prerevolutionary colonies. ${ }^{\text {.3 }}$

Unfortunately, the continental hyperinflation had fractured the prerevolutionary consensus regarding the usefulness of paper currency. People who had accepted continentals or continental-denominated securities from government or private parties were outraged that the states ap- peared to have no intention of redeeming them at anything close to the values at which they had traded during the early years of the war. Indeed, the propertied classes came toview paper currency as a device by which popularly elected governments sought to permit the common people to escape the burden of their public and private debts. (The lengthy trade depression that followed the end of the war had increased private debt burdens.) Wealthy Americans became terrified that the state legislatures, which were now free from British restraint, would reprise the Revolutionary experience by issuing large volumes of inadequately backed legal tender bills--bills which would rapidly depreciate, and which could be used to retire debts at a fraction of their real value. As a result, proposals to issue paper currency that would have received consensus support before the Revolution now became the subjects of intense political controversy. ${ }^{64}$

In Rhode Island, radical populists gained control of the legislature. They confirmed the worst fears of the anti-paper money conservatives by issuing a legal tender currency, and then engineering a rapid inflation that seemed clearly designed to enable borrowers to escape their debts. ${ }^{65}$ In Massachusetts, an agrarian insurrection (Shay's Rebellion) erupted as a result of the refusal of the legislature to issue legal tender paper currency. ${ }^{6}$

As it happened, the Constitution was written and ratified during a period of conservative ascendancy - a reaction against excesses of the sort epitomized by events in Massachusetts and Rhode Island. ${ }^{67}$ The conservatives desired a "hard" currency immune from depreciation. As a result, the framers of the Constitution were not content merely to deprive the states of the right to issue legal tender bills; instead, they were prohibited from issuing currency of any kind. Specie was established as the new nation's sole legal tender currency-and, in the minds of many, as the nation's only legitimate currency.
62For a good account of the history of the Continentals, and indeed of Revolutionary War finance, see Ferguson (1961). See also Calomiris (1988).

${ }_{63}$ For general discussions of currency issues by (incipient) states during the critical period, see Nevins (1924), Ferguson (1961), Nettels (1962), Russell (1988) and Schweizer (1989).

E4For descriptions of public attitudes toward paper currency during the critical period, see Libby (1894), Hammond (1957) and Ferguson (1961).

65Most of the other colonies that issued legal tender bilis also experienced serious depreciation-though not on the scale of
Rhode Island. On the other hand, colonies that issued nontender bilis experienced little or no depreciation. For a discussion of this question, see Russell (1988). For descriptions of Rhode Island's post-revolutionary currency policy, see Philtips (1865), Bates (1898), Nevins (1924) and Ferguson (1961).

66The classic study of Shay's Rebellion is Taylor (1954).

${ }^{67}$ This point is made by Ferguson (1961), pp. 249-250. Nevins (1924), p. 537, and Schweitzer (1989), pp. 319-320. 
Thus the peculiar historical circumstances of the post-revolutionary critical period had a profound and lasting impact on the nature of the U.S. monetary system. The trauma of the Revolution made the currency system controversial, and ultimately produced a system very different from the relatively uncontroversial system of late colonial times. Indeed, it seems likely that had the colonies been able to escape British domination without fighting an expensive war, or had the principal casus bellum not been one which required that the war be financed by means which sowed the seeds of a divisive struggle between classes, the United States might have begun its existence with a decentralized currency system based on (non-legal tender?) bills of credit issued by state governments. ${ }^{68}$

The Constitution was silent on the question of privately issued currency. Indeed, during the years immediately following its ratification, issuance of small-denomination liabilities which might circulate as currency (which might "pass current," to use the contemporary phrasel was regarded as a right of all free persons. By the second decade of the nineteenth century, however, the legislatures of most of the states had acted to eliminate or greatly restrict that right. ${ }^{69}$ There were at least two reasons for this, One was the problems caused by irresponsible, or downright fraudulent, private issues. Another, which was perhaps more compelling, was the desire of the state legislatures to re. serve the right of note issue to state-chartered banks. ${ }^{7:}$

The Constitution had also been silent regarding the right of the states (or the federal government) to charter banks of issue-perhaps because private banking had little history in the colonies. In Massachusetts, the most economically sophisticated colony, efforts to organize a private land bank along the lines of public land banks began late in the seventeenth century and persisted episodically for the next five decades. The mercantile community was somewhat skeptical of land banking, however, since it threatened to compete with their own lending activities. Merchants in the coastal cities provided a good deal of trade credit to the merchants and farmers of the interior.] In addition, the colonial authorities (both administrative and legislative) were reluctant to give up their monopoly over paper currency-partly out of fear that a form of money issued outside of official control might be subject to manipulation, and partly out of concern that it might reduce potential revenues from seigniorage. Although various private land bank projects received considerable popular support, they were unable to surmount this political opposition. ${ }^{71}$

By 1740 , however, the restrictions on colonial issues which had been imposed by the British government had become so onerous (land bank issues, in particular, had been entirely prohibited) that the Massachusetts legislature was willing to charter a private land bank. While the land bank project received broad support from the public, it was vehemently opposed by the colony's governor (a creature of the British), who viewed it as weakening the mother country's control over the colony's economy. The land bank was also opposed by British merchants, who saw it as a threat to their near monopoly over trade credit. Both groups appealed for relief to Parliament, which responded by enacting legislation prohibiting the establishment of banking corporations anywhere in the colonies. ${ }^{72}$

The legislatures of the newly independent states saw chartered banking as a means by which they could provide their citizens with paper currency while at the same time (in many cases) providing
68Many historians believe that resentment over British efforts to regulate colonial currency practices played a major role in stimulating the Revolution. [See Bullock (1900), pp. 56-59, Davis (1900), vol. 1, chapter XXI, vol. 2, pp. 256-61, Brock (1975), pp. 561-63, Billias (1959), p.42, and Ernst (1973), pp. 359-60, for example.] This makes it seem very ironic that the currency restrictions the U.S. Constitution imposed on the states were generally more restrictive than any the British had ever imposed. [One exception is that the states could charter private banks of issue, something the British had prohibited the colonies from doing. It is not completely clear that the framers actualiy intended to authorize state-chartered banking, however (see below).]

69 See Hammond (1957), pp. 27-29, 184-85 and Fenstermaker (1965a), pp, 2†-22.

70 Both these motives are mentioned by Hammond (1957), pp. 27-29, 159-60, 184-85. See also Fenstermaker (1965a), pp.
15-16. The importance of the latter motive is indicated by Hammond's comment that restrictions on unincorporated note issue were enacted "on the complaint of chartered banks"' (p. 184).

71 In 1714 there was a welf-organized and determined attempt to organize a private land bank - an attempl which was supported by some influential British merchants, and received the endorsement of the Board of Trade. The government of Massachusetts responded by establishing a pubtic land bank. See Billias (1959), pp. 3-5, Nettels (1934), pp. 271-275, Davis (1900), volume I, pp. 56-61, volume ll, pp. 82-91, Ernst (1973), pp. 27-28, and Metz (1945), chapters 3,4.

72See Billias (1959), Davis (1900), volume l, pp. 130-261, Hammond (1957), pp. 24-25, Brock (1975), pp. 123،27, Ernst (1973), pp. 34-35, and Metz (1945), chapter 10. 
themselves with revenue. Of course bank charters would be more valuable to their holders, and thus issuing charters would be more lucrative for the states, if the charters conveyed an exclusive right to issue paper currency. This accounts for the prohibitions against private issues from other sources. ${ }^{73}$

But what sort of banks should the states charter? While it might seem that the colonies' extensive experience with public land banks should have led them, as states, to charter private land banks, they did not in fact do so. Two factors may help explain this situation. The first is that the right of the states to charter banks of any sort was not altogether clear; indeed, the view that they did not have this right was widely held. ${ }^{74}$ Doubts about state charter rights seem to have existed on two levels. Many, and perhaps most, informed Americans believed that the Constitution established specie as the only legitimate form of "money." The question then became "What is "money"? and, in particular, "Are bank notes "money?" A conservative view was that the category "money" did include bank notes, and indeed paper bills of all descriptions, so that paper currency in ary form was proscribed. A more moderate view was that bank notes convertible in specie were not money, but merely its "representative," and thus were not constitutionally prohibited. ${ }^{75}$ This view implied that private land banking conducted along colonial lines, which is to say through the issuance of inconvertible notes, involved direct creation of money, and was there. fore unconstitutional-even if the bills were not legal tender. ${ }^{76}$

A second possible reason why the states did not opt for some form of land banking was that, given their British-imposed lack of experience with private banking, their only models for bank charters were those of British banks-which meant, for all intents and purposes, the charter of the Bank of England. Indeed, the charters of many of the earliest state banks were virtual carbon copies of the Bank of England's charter. The attractiveness of the British model may have been enhanced when, shortly after the Constitution was ratified, the Federal government decided to seek a charter for a single "National Bank" along the lines of the Bank of England. This institution was called the "Bank of the United States," and was established in 1791 with a 20 -year charter. Though the U.S. Bank was basically a private organization, the Federal government held a minority interest, and the Bank was expected to provide a variety of financial services for the government in addition to its private lending activities. ${ }^{7}$ The early state banks seem to have been intended as state versions of the U.S. Bank. This is reflected in the fact that until the charter of the U.S. Bank expired in 1811, most states chartered just one or, at most, a handful of banks. ${ }^{78}$

The failure of the first U.S. Bank to secure a new charter was due to a combination of doubts about its constitutionality, suspicion of its power, and discomfort with the fact that much of its stock was foreign-owned." The demise of the bank coincided with a period of national economic expansion associated partly with the impact of the Napoleonic Wars on commodity prices, and partly with the settlement of the western (trans-Appalachian) region. Across the United States, and particularly in the new statesand

\footnotetext{
73The motives (and actions) of the states in this regard were similar to those of any license-granting monopolist. The strategy was evidently based on the British example. During the eighteenth century, the British government had repeatedly extracted large payments, or loans on favorable terms, from the Bank of England in relurn for extending or strengthening its monopoly on note issue. A distincively American variant of this strategy was for a state government to zequire a bank's organizers to cede the state an equity interest in return for granting the bank a charter. Sometimes the interest was ceded gratis, and sometimes metely on favorable terms. This practice was particularly common in the southeastern states. In several of these states bank dividends accounted for a substantial portion of state government revenues. [See Fenstermaker (1965a), pp. 17-20. For a thorough analysis of the importance of dividends from bank stock in state government finance during this period, see Syila, Legler and Wallis (1987).]

${ }^{74}$ For a general description of the nature and source of doubts about the constitutionality of state banks see Hammond
}

(1957), pp. 103-13, 564-71, and Hurst (1973), pp. 11-12, $141-45$.

75 See Hammond (1957), pp. 61, 105-06, Gallatin (1879), pp. 254-55, (1879), p. 379, Bancroft (1831), p. 40.

76 The relatively radical view that private or even public land banking was consistent with the Constitution, so long as the states did not try to make the notes of such institutions legal tender (or even, perhaps, if they did), did not become popular until the economically troubled period following the Panic of 1819 .

${ }^{77}$ For the history of the first U.S. Bank, see Holdsworth (1910).

7 For information concerning state banks chartered before 1819, see Fenstermaker (1965b).

79 See Hammond (1957), pp. 209-26, and Holdsworth (1910). 
territories of the West and South, banks were chartered in large numbers. ${ }^{80}$ These new banks differed from the established banks in one critical respect: they were organized primarily to provide credit to farmers. ${ }^{g t}$

\section{Economic Depression and Its Consequences}

Synopsis: The lengthy and severe depression that followed the Panic of 1819 placed great strains on the U.S. banking and currency system. The crisis exposed a basicinconsistency between two goals of the developing banking system: specie convertibility of bank currency, on one hand, and liberal extension of farm credit, on the other. Many of the southern and western states, in which farmers predominated, responded by experimenting with systems in which banks issued in. convertible notes. While some of these systems were clearly not viable, others appear to have had promise. The federally chartered Bank of the United States intervened to put an end to all of them, however.

At this point in U.S. history, a conflict arose between the needs of economic development and the devotion to "hard money" which grew out of the Revolution. Economists since the time of Adam Smith had understood that banks which issued convertible notes, and thus were vulnerable to runs, could not safely lend to farmers: farm loans were typically long term, illiquid and relatively risky. ${ }^{32}$ The need for farm credit was sufficiently great, and public understanding of banking sufficiently slight, however, that the legislatures of the southern and western states permitted (and indeed encouraged) their banks to finance large quantities of farm credit by issuing convertible notes. ${ }^{83}$

The collapse in agricultural prices which occurred during 1818-19 (and led to the Panic of 1819) made the two mandates of the southern and western banks-prompt specie redemption of notes, and liberal extension of farm credit-impossible to reconcile. ${ }^{84}$ The price collapse produced widespread loan defaults and runs on banks. Since agricultural loans were impossible either to collect or to sell in a short time, the runs could be stopped only by suspending specie payments - by refusing to redeem bank notes in specie on demand. Even after the runs subsided, however, the defaults represented tremendous losses for the stockholders of banks that were willing, or could be compelled, to honor their convertibility commitments. Indeed, a large number of western banks had become insolvent ${ }^{85}$ The managers of the southern and western banks responded by declining to resume payments, and their notes continued to trade at substantial discounts in the open market. The holders of these notes were forced, in effect, to bear some of the financial losses associated with the Panic.

The governments of the western and southern states responded to this situation in very different ways. Most western states had banking systems composed of large numbers of relatively small banks. Since the losses associated with the price collapse and Panic were particularly heavy in the West, most western banks were insolvent, or nearly so; their notes were trading far below par. Many westerners viewed the events of 1818-19 as a conspiracy on the part of the "monied interests" to ruin them and seize

80At the time, the western region included western Pennsyl vania, Ohio, Kentucky, Tennessee, Indiana, Illinois and Missouni. (The following account applies most closely to the experience of the last five states listed.) The southern region included Virginia, North Carolina, South Carolina, Georgia and Alabama. (The following account applies most closely to the experience of North Carolina, South Carolina and Georgia.)

For information concerning state banks chartered before 1837 see Fenstermaker (1965a).

81For a discussion of the development of agricultural (and other types of long-term) banking see Hammond (1934), Hammond (1957), pp. 676480, and Redlich (1951), vol, pp. $11-13,44-45$.

gamy tarm loans were seasonal loans to funarce planting or harvesting the crop. Variation in weather conditions and crop prices could make such loans quite risky, and by contemporary commercial standards they were relatively long term. However, a good deal of farm credit involved much longer-term loans to finance the purchase and/or clearing of land, the purchase of equipment (and in the South, slaves), etc. Mos: loans for these purposes were "accommodation loans." An accommodation loan did not

have a fixed term; the borrower was expected to pay an "instalment" equal to a fixed fraction of the principal (typically, 10 percent) every 90 days. In practice, installments could be deferred and/or reduced, so that the lifespan of an accommodation loan could greatly exceed the term implied by these conditions. Crop loans might also be extended as accommodation loans, with the presumption that they would be fully repaid at the end of the season. Very ofien adverse circumstances made this impossible, however. See Fenstermaker (1965a), pp. 47 49, Redlich (1951), volume $1, p .11$, Holder (1937), pp. 119-22, and Russell (1989a), pp. 69-73.

83See Hammond (1957), pp. 178 83, Redlich (1951), pp. 9-12.

${ }^{84}$ For descriptions of and data on the price collapse, see Cole (1938), Berry (1943), Smith (1953) and Aussell (1989c)

85A list of the banks which failed during or shorty after the Panic can be compiled from information presented by Fen stermaker (1965a). Berry (1943) provides information concerning bank failures in ohio during this period. 
their property. The banks, they believed, had been agents of this conspiracy. Consequently, the western legislatures moved to revoke their charters and/or to force them to liquidate. Private banks were replaced by monolithic, statemanaged organizations called "Banks of the State" or "relief banks." They were supposed to lend inconvertible notes which would be given quasilegal tender status by their states. ${ }^{86}$

The history of the relief banks was brief, controversial, and generally undistinguished. Since their mandate was to lend liberally to financially distressed farmers, the market value of their loan portfolios was low relative to the nominal value of their outstanding notes. This circumstance was reflected in the deep discounts on the notes ${ }^{87}$ The lending standards of the llinois relief bank were so lax, and its efforts at collection so ineffectual, that its notes soon became virtually worthless. ${ }^{s 8}$

Both the legislation that created the relief banks and the "stay laws" which made their notes quasi-legal tender were of doubtful constitutionality. These laws were challenged vig. orously in state and federal courts. In Kentucky, Tennessee and Missouri, these challenges ultimately led to the demise of the relief banks.

Some of the federal court challenges were orchestrated by the second Bank of the United States. In 1816, Congress had responded to financial problems created by the War of 1812 by chartering a second U.S. Bank. The new bank was (again) a private institution, though the federal government held a sizable minority interest. The term of its charter was 20 years. ${ }^{8.9}$

The U.S. Bank's charter required its notes to be strictly convertible. The Bank's management believed that it could circulate convertible notes in the west and south only if the notes of its lo. cal competitors were also convertible. The man. agement also believed that acquiring a large local circulation was essential if the Bank were

${ }^{86}$ The best available account of the Panic and its aftermath is Rothbard (1962).

The legislatures of these states enacted "stay taws" which provided that foreclosures and other legal actions for the collection of delinquent debts ("executions," to use the contemporary description) could be delayed for long periods-typically a year or more-unless the creditors in question were willing to accept Bank of the State notes at par. See Rothbard (1962), chapters II, HI.

${ }^{87}$ Data on the discounts on the notes of the Kentucky relief bank are available from Berry (1943) and Sumner (1896). Fenstermaker (1965a) presents somewhat less complete information on the discounts on other relief bank currencies. to earn a profit on its southern and western operations, or effectively perform its duties as the payments agent of the federal government. ${ }^{90}$ The Bank consequently made strenuous efforts to force the western banks to return to the specie standard. This policy allowed it to extend the scope of its activities in the West, while striking a pose as the defender of sound currency. In the meantime, bitter political controversy over the redistributive implications of the activities of the Banks of the State greatly reduced their effectiveness. ${ }^{91}$

In many ways, the relief banks were direct descendants of the public land banks that had been quite successful, and had enjoyed consensus public support, during the years preceding the Revolution. Unfortunately, the extraordinarily adverse economic circumstances which led the western states to circumvent the Constitu tion by creating these institutions also served to ensure their ultimate demise. The relief banks were created by the state legislatures for the purpose of relieving the financial plight of their constituents, rather than to provide a sound currency, or to earn revenue (which is to say profits) for the states. ${ }^{2}$ This mandate, combined with the depth of the agrarian distress, made it impossible for the banks' managers to resist making too many loans to troubled farmersm who were already burdened with debt and whose ability to repay was very doubtful. The same circumstances led the states to supplement the relief bank legislation with stay laws and related provisions. These provisions made the banks extremely controversial, eaming them the enmity of creditor interests in general and the powerful United States Bank in particular.

The failure of the relief bank experiment had an effect on public attitudes toward monetary issues that was reminiscent of public reaction to the Revolutionary hyperinflation. People became increasingly suspicious of banks and paper cur-

86ee Rothbard (1962), pp. 41-42, 80-83; see also Dowtie (1913).

89 See Catterali (1902), chapter 1.

90See Catterall (1902), pp. 96-99, Redlich (1951), pp. 109-10, $124,128-29,440-44$, Temin (1969), p. 49, and Fraas (1974).

${ }_{91}^{9}$ For accounts of the demise of the relief systems, see Rothbard (1962), Chapter 1li, Hammond (1957), pp. 282-285, and Sumner (1896).

92See Fenstermaker (1965a), pp. 26-27, Rothbard (1962), pp. 81483, 85-86, 102-03, and Sumner (1896). 
rency, and increasingly enamored with "hard money"-specie, or bank notes rigidly convertible into specie. The demise of the relief banks also gave the Bank of the United States a virtual monopoly over banking in much of the West.

The southern states tried a different-and initially, at least, more promising-experiment with inconvertible banking. The southern banks, unlike their western counterparts, were large but few in number; frequently, they operated branches across their respective states. The southern state governments held large minority interests in these banks. Since the dividends on the shares provided an important source of state revenue, the state legislatures had no desire to see the banks close down. ${ }^{93}$ In addition, since the financial distress that accompa nied the Panic was less severe in the South than in the West, the popular outcry against the banks was somewhat less strident there. Finally, because of their large size and branch systems, the banks of the region were more effectively diversified than their western counterparts, and requirements imposed by their charters had kept them relatively highly capitalized.

When the southern banks suspended the convertibility of their notes, the governments of the southem states did not force them to liquidate, or even to close down. Instead, the banks were permitted, and often encouraged, to continue to do business-lending, collecting on loans, and conducting other financial transactions, all through the medium of their now-inconvertible

93 See note 73 above

94 For a description of banking in North Carolina after the suspension, see Russeal (1989a)

95Note discount data for North and South Carolina state banks during 1817-1829 are provided by Russell (1989a). Fenstermaker (1965a) provides less complete data for all the southern states.

96 For expressions of this view see Gouge (1833), Sumner (1896) and Klein (1974).

97 Before the suspensions, the notes of southern state banks had traded at or near par with specie; afterwards, they traded at variable discounts. Thus it seems clear that the suspensions exposed noteholders to risks they had not previousty borne. The author believes that after the suspensions, the market priced bank notes in much the same manner as modern mutual fund shares. This sort of pricing scheme would have linked the value of a bank's notes to the value of its assets-a link which was absent under convertiblity. [See Russell $(1989 b, c)$.] Other theories of inconvertible note pricing have broadly similar implications, however. The most popular alternative theory is that the notes of a suspended bank were priced as risky tifles to future specie, payable if and when the issuing bank resumed payments. Since the state of a bank's porffolio was probably the biggest single factor influencing the prospect that it would be able to re notes. ${ }^{94}$ These notes dropped to variable discounts (against specie) in the open market. Variation in these discounts seem to have reflected changing market conditions-much like the variation in modern national currency exchange rates. ${ }^{95}$

Economic historians have usually viewed the suspensions as irregular events completely inconsistent with the maintenance of monetary and financial stability, ${ }^{96}$ There are good practical and theoretical arguments against this view, however. On a practical level, the banks stayed in business, and continued to supply badly needed currency and credit, despite the depressed conditions created by the collapse in prices and the financial panic. This situation stands in marked contrast to that of the West. There, the banking system collapsed, and a scarcity of currency and credit threatened to bring economic activity to a standstill.

On a theoretical level, the suspensions shifted some of the burden of the banks' portfolio risk from shareholders to noteholders. ${ }^{97}$ The price collapse and panic had revealed the true extent of the risks the banks faced, and had exacerbated the already acute scarcity of financial capital-particularly concentrated financial capital-in the relatively undeveloped southem states. $^{98}$ Under these circumstances, it seems doubtful that current or future bank shareholders would have been willing to continue to bear all of the banks' portfolio risk-particularly in light of the heavy losses that a prompt return to specie payments would have imposed. ${ }^{9}$ sume, this theory also implies that the holders of inconvertible bank notes were bearing portfolio risk. And because all of the portfolio risk had to be borne by the holders of the banks' liabilities, any risk borne by noteholders reduced the risk born by shareholders (and vice-versa).

Another alternative theory is that bank notes traded at a discount during suspension because holders' inability to convert them into specie temporarily reduced their usefulness, relative to specie, as media of exchange. Advocates of this theory typically view suspensions as a sort of "safety valve" protecting fractional reserve banking systems operating under laissez-faire-operating without, that is, government deposit insurance and/or a government lender of last resort. For expressions of this view see Friedman and Schwartz (1963), pp. 163-68, 324-32, and Dwyer and Gilbert (1989).

98 The charters of contemporary banks specified minimum denominations for shares which were usually well out of reach of the common people. The rationale behind these minima is not entirely clear. See Russell (1989a), pp. 35-36.

g9The North Carolina banks, in particular, decided to close down when specie payments were finally imposed on them in 1828-1829. See Russell (1989a), pp. 25-32, 78-80, Holder (1937), pp. 250-51, and Flanagan (1934). 
A case can be made that the post-Panic suspensions began a process which, had it been allowed to proceed unhindered, might have enabled the South to develop an alternative banking system which was peculiarly suited to its distinctive needs. Because the southern economy was dominated by agriculture, banks could be useful to southern economic development only if they were able to make farm loans in large volumes. Farm loans, however, were relatively risky -and under convertibility, these risks were borne almost exclusively by bank stockholders. These stockholders had both the opportunity and the means to lend outside the South, and could be induced to take these large risks only in return for high average rates of return. Such rates would have made bank credit too expensive for many farmers-and usury laws might have prevented the banks from charging them in any case. One solution to this problem was the development of an alternative banking system which could bring the diffuse financial capital of the common people into the risk-bearing process. Inconvertible private banking seems to have had the potential to provide such a system. ${ }^{\text {ino }}$

Unfortunately for the southern banks, both the federal government and its financial agent, the Bank of the United States, regarded the suspensions with almost unalloyed hostility. The U.S. Treasury Department was deeply (and somewhat irrationally, under the circumstances) committed to fiscal arrangements under which payments to the federal government (for taxes, land purchases, etc.) were made exclusively in par currency. ${ }^{101}$ Southerners, however, were used to making government payments in local (bank) currency, which was no longer trading at par. The Bank of the United States, which was charged with the responsibility of receiving and clearing the pay. ments, found itself wedged very uncomfortably in between. If the Bank accepted discounted state bank notes at par for government payments, the Treasury would insist that it clear them at par, and the Bank would take large exchange losses. If it did not accept state bank notes at all, it would at the very least offend the people of the South $-\mathrm{a}$ region where it greatly desired to extend its business-and might well materially increase their economic troubles. The Bank would also offend the Treasury, its patron, which wished to ensure that federal payments could be made in currency readily available to the public. ${ }^{102}$ Finally, if the Bank accepted state bank notes at their market rates of discount, it would be accepting a situation which, it believed, prevented it from operating profitably and effectively in the region. ${ }^{103}$

The Bank's problems would have been solved if the southern banks had resumed specie payments promptly after the Panic. When they did not, it launched a campaign to force them to do so. It continued to accept discounted state bank notes in payment of federal debts and, when it had accumulated them in large quantities, presented them at the counters of the state banks for payment. When the southern banks refused to pay, the U.S. Bank filed suit against them in federal court. ${ }^{104}$

While the suspensions had no formal legal validi. ty-in principle, each bank note was redeemable at par and on demand, and a bank which declined to redeem its notes had defaulted on its debts-they were implicitly (and sometimes explicity) tolerated by state legislatures and courts. The U.S. Bank, however, was in a position to sue in federal courts, which provided the state banks no such protection. ${ }^{105}$
${ }^{100}$ This argument is presented in detall in Russell $(1989 a, b)$

1014t seems itkely that the exchange problems described here could have been avoided if the Treasury had been willing to accept and disburse state bank notes at their market rates of discount. A similar situation had arisen after the general suspension, of specie payments which occurred in August of 1814 , near the end of the War of 1812 . During the months after the suspension, the Treasury needed funds to service debt held by residents of New England. New England was the only region of the United States in which the banks had not suspended specie payments, so New England bank notes were trading at par with specie. Unfortunately, most of the federal government's revente was received in the mid-Atlantic region. The mid-Atlantic banks had suspended, and their notes were trading well below par. The Treasury insisted on accepting local currency at par in payments to the federal government, and on disbursing such currency only where it would be accepted at par. This torced it into temporary default on its debt service payments, despite its large balances of midAtlantic bank notes. See Catterall (1902),pp. 4-7, and Bancroft (1831), pp. 47-49. to2for a general description of the U.S. Bank's problems as a federal collection and clearing agent, see Catterall (1902). For accounts of its disputes with the banks of Georgia and North Carolina, see Govan (1937), Heath (1954), Holder (1937) and Russell (1989a). These accounts are based on correspondence between the U.S. Bank, the Treasury Department, and the state banks that is recorded in the American State Papers, Finance, Volume 4.

103 See note 90 above.

${ }_{104}$ Govan (1937) and Russell (1989a) describe federal court suits filed by the U.S. Bank against state banks in Georgia and North Carolina, respectively.

105See Hammond (1957), pp. 283-84, and Russell (1989a), pp. 42-43. The efforts of various southern and western states (notably Georgia) to evade adverse federal court decisions concerning the U.S. Bank were ultimately rejected by the U.S. Supreme Court. See Catterall (1902), pp. 88-91, Govan (1937), and Hammond (1957), pp. 263-68, 272-73. 
The efforts of the U.S. Bank slowly forced the banks of the various southern states to resume payments: Virginia and South Carolina in 1823 , Georgia in 1825, Alabama in 1827 and North Carolina in 1828. In view of the conventional wisdom regarding suspensions, it should come as no surprise that most economic historians have regarded the Bank's resumption campaign as virtuous and constructive; the Bank is lauded, in particular, for having created a "uniform national currency."106 Southern farmers, and other southerners whose livelihood was based, directly or indirectly, on farming-groups which collectively comprised the bulk of the region's population-had less reason to sing the Bank's praises. The cost of resumption was that state banking systems (or those portions of them which survived) became reluctant to lend to farmers. Since there were few alternative sources of credit available, farm loans became substan. tially more difficult to obtain. ${ }^{107}$ It should thus be equally unsurprising that, just a few years later, the southern states were in the forefront of the opposition to the Bank's efforts to secure a new charter. ${ }^{108}$

\section{A Bank War and the Rise of Free Banking}

Synopsis: The political controversy that led to the demise of the Bank of the United States had a profound effect on public attitudes toward the banking and currency system. The American public became suspicious of any hint of monopoly power in banking and of any link between the federal government and private banks. It also became increasingly devoted to the concept of hard money. One outgrowth of these attitudes was that many states adopted laws providing for "Free Banking." Free bankinglaws encouraged entry into banking, and resulted in the establishment of large numbers of banks. The free banks were heavily regulated, however; their notes were to be carefully secured, and strictly convertible. Other results of changed public attitudes were the "Specie Circular" and the "Independent Treasury." The federal government became reluctant to accept bank currency in payment, and attempted to conduct its financial operations without the aid of banks.

The election of 1828 transferred control over the federal administration from the Whigs, led by defeated President John Quincy Adams of Mas. sachusetts, to the Democrats, led by Presidentelect Andrew Jackson of Tennessee. The Democrats regarded themselves as the party of the com. mon (and thus largely agricultural) people; they had long been advocates of competitive, decentralized state banking and opponents of the Banks of the United States. The party also contained a hard money faction which was deeply suspicious of banking of any kind. Jackson himself seems to have had somewhat ambiguous feelings toward banking. On one hand, many of his principal advisors were men who had defended the relief banks and bitterly resented the damage the U.S. Bank had done to the banks and people of the western states. Some of these men were now connected with the state banks, and thus tended to formulate policies which favored their interests vis-a-vis those of the U.S. Bank. On the other hand, Jackson is said to have been personally opposed to banking and paper currency of any sort; late in his administration he took actions that greatly increased the problems of the state banking systems. ${ }^{109}$

Jackson's State of the Union message in 1829 came out against the recharter of the United States Bank. (The Bank's charter did not expire until 1836, but its friends in Congress had begun to agitate for an early recharter act.) Jackson argued that the Bank's constitutionality was doubtful, and that its concentrated financial power was inconsistent with the tenets of representative democracy. Jackson's message marks the beginning of the "Bank War," a period of five years or so during which the Whigs (who controlled Congress) attempted to defend the Bank against the increasingly vituperative attacks of the Democratic administration. During this period, the "Bank question" became the single biggest issue in national politics. The Democrats 1065ee in particular Catterall (1902), Redich (1951), Hammond (1957) and Temin (1969).

${ }^{107}$ For the case of North Carolina, see Russell (1989a), pp. 71-74. In 1828, Georgia established the Central Bank, a state-owned institution designed to extend long-term loans to farmers and planters. Heath (1954) ascribes this decision to a shortage of long-term commercial bank credit that developed during the 1820 s.
${ }^{108}$ Catterall (1902), pp. 164-65, 235, Hoyt (1960) and Wilburn $(1967)$, pp. $7-11,17-19$, describe southern support for the Bank War.

${ }^{109}$ For descriptions of Jackson's attitude toward banking in general, and the United States Bank in particular, see Catterall (1902), pp. 182-85, Schlesinger (1953), pp. 76-78, Redlich (1951), pp. 162-71, Hammond (1957), pp. 346-50, and Temin (1969), chapter 2. 
simultaneously exploited and encouraged public feeling against the banks so as to build up their political power base at the Whigs' expense. After Jackson was re-elected in 1832 the issue came to a head; Congress passed legislation rechartering the Bank, Jackson vetoed the legislation, and Congress failed (narrowly) to override his veto. The second U.S. Bank effectively ceased to exist as a national institution when its federal charter expired in 1836; its relationship with the federal government had been severed, and its power thus greatly reduced, two years earlier. ${ }^{110}$

The demise of the U.S. Bank raised two important questions: how should the federal government administer its financial affairs, and how should the states regulate their banking systems? The first question arose because the U.S. Bank had acted as the financial agent for the U.S. Treasuryin other words, as the federal government's bank. The second arose because the U.S. Bank no longer existed to regulate the state banks and, in particular, to enforce specie payments. By the second half of the 1830s, Jacksonian hardmoney notions had become so pervasive that few people were prepared to accept a return to relatively laissezfaire banking, or to a currency which might come to consist largely of inconvertible bank notes. The effect of the Jackson Administration's anti-U.S. Bank campaign on a financially unsophisticated public had been to exacerbate its doubts about and suspicion of all banks and all paper currency. ${ }^{111}$

The Jackson and Van Buren Administrations [Martin Van Buren, who was elected president in 1836, had been Jackson's vice presidentl responded to the first problem with two policy initiatives. The first was an executive order called the specie Circular, issued in 1836, shortly before Jackson left office. This order directed the U.S. Treasury to accept no currency other than specie in payment of debts to the federal government. ${ }^{112}$ The second policy initiative was the Independent Treasury Act, a product of the Van Buren Administra- tion. This Act withdrew the U.S. government's cash deposits from the large state banks (sometimes called pet banks) where they had been placed after the demise of the U.S. Bank. Henceforth, the Treasury would act as its own banker. The net effect of these two actions was profoundly antibanking. The federal government would no longer deal with the state banks, or encourage (or even recognize) their note circulation. ${ }^{113}$

The states' response to the problem of bank regulation reflected two features of public attitudes towards banking which had grown out of the Bank War: suspicion of concentrated financial power, and preference for "hard money." Under the bank chartering system that existed in most states prior to the late 1830s, the issuance of a charter required a special act of the state legislature. The process of securing legislative assent was lengthy, cumbersome, uncertain and occa" sionally corrupt; in addition, banks that already possessed charters generally lobbied vigorously against the issuance of new ones. The upshot was that most states had a relatively small number of banks, and that these banks possessed, or were believed to possess, considerable market power. ${ }^{114}$

The "free" in the free banking laws reflected the desire to reform the chartering process in the direction of free entry. Each state would formulate a standardized charter, and any individual or group which was able and willing to meet the terms of this charter could organize a bank in that state. The free banks would be regulated by the state auditor, or by a state banking agency created for that purpose; the legislature would be involved only indirectly. This system was intended to greatly increase the number of state banks. ${ }^{11.5}$

There is another sense in which the term "free banking" is a misnomer, however. Free banking was not in any sense laissez-faire or unregulated banking. The standardized charters imposed numerous and relatively stringent restrictions on the banks' capitalization and reserves, the condi-

\footnotetext{
110For accounts of the Bank War, see Catterall (1902), Hammond (1957) and Schlesinger (1953), among many others.

111 For a description of the Loco Focos (formaly, the Equal Rights Party), a party of antibanking radicals which arose during the Bank War and was uttmately instrumental in the rise of Free Banking and the Independent Treasury, see Redlich (1951), pp. 188-90, Hammond (1957), pp. 493-99, and Schlesinger (1953), chapters XV-XVI.

${ }^{112}$ For analyses of the motivation behind, and/or the impact of, the Specie Circular, see Hammond (1957), pp. 455-57, Schlesinger (1953), pp. 129-31, Smith (1953), p. 185, Temin
}

(1969), pp. 120-28, Timberlake (1960) and Timberlake (1978), chapter 5 .

113 For discussions of the role of the Independent Treasury see Hammond (1957), pp. 542-45, Taus (1943) and Timberlake (1978), chapter 6 .

114See Hammond (1963), pp. 7-8, (1957), pp. 577-80, Redlich (1951), pp. 188-90, and Schlesinger (1953), p. 286.

115 for discussions of the rationale behind Free Banking see Redlich (1951), pp. 187-204, and Hammond (1957), pp. $572-80$. 
tions under which they could issue notes, and the types of assets they could hold. These restrictions were designed, in the "hard money" spirit, to ensure that the banks' notes would always be convertible on demand, and that they would be relatively immune from losses associated with declines in the value of the banks' assets. One restriction was so common that it has come to be regarded as characteristic of free banking: the notes of the free banks had to be 100 percent backed by holdings of state or federal government securities. ${ }^{116}$

Free banking experienced some problems, especially during its early years. It seems in particular to have been characterized by a relatively high rate of bank failures. These failures, and a few notorious instances of fraud, have given the system a bad reputation among historians. ${ }^{117}$ There were also many complaints that the need to keep track of the market values of the many different types of bank notes in circulation-some of which were counterfeit or issued by failed or insolvent banks-materially reduced the effectiveness of bank currency as a medium of exchange. ${ }^{118}$

Recent research has revealed that the losses to noteholders associated with free bank failures were actually quite small on average. ${ }^{119}$ Ironically enough, many of the losses and failures that did occur were caused by defaults on state government bonds, which were widespread during the 1840 s and 1850 s. $^{120}$ Entrepreneurs responded to the diversity of bank currencies by publishing "bank note reporters" in which the value of different bank currencies were recorded, insolvent banks identified, and the appearance of common counterfeits described. ${ }^{221}$ The system worked well enough that, until the Civil War broke out, there seems to have been little political support for any federally dominated alternative. Additional evidence that contemporary legislators

116See Rockoff (1975), pp. 2, 81 87, and Rolnick and Weber (1984), (1988).

117 For unsympathetic descriptions of the record of Free Banking, or references to such descriptions, see Cagan (1963), pp. 19-21, Friedman (1960), p.6. Hammond (1957), pp. 723, 741-42, (1963), Rockoff (1975), pp. i-ii, and Rolnick and Weber (1983).

118See Cagan (1963), pp. 19-20, Hammond (1957), pp. 722-23, (1963), p. 14, and Rockoff (1975), pp. 26-29.

119Rockoff (1975) and Rolnick and Weber $(1983,1988)$ use data drawn from state auditors' reports to provide careful estimates of the cosis of free bank failures. Rockoff estimates that the total losses endured by free bark noteholders from 1836 through 1860 were less than $\$ 2$ million-about the cost. viewed free banking as viable is provided by the fact that new states continued to adopt free banking laws through the early 1860s. Rockoff (1975) notes that "on the eve of the Civil War over half the states, including the most populous states, had free banking laws." 122

\section{The Civil War and the Demise of State Bank Currency}

Synopsis: The changes in the American cur" rency system produced by the Civil War were almost as profound as those produced by the Revolutionary War. When the Civil War began, the U.S. had a relatively decentralized system in which paper currency was issued by state-chartered and -regulated banks; the federal govermment had no role in the provision of paper money, and there seemed little prospect that it would acquire one. When the war ended, the nation had a relatively centralized system in which paper currency was issued by federally chartered and regulated banks; it was no longer possible for state banks to issue paper money. In addition, the federal government had acquired and used the power to issue paper money and to make it legal tender. This huge, rapid transformation was possible for two reasons. First, the war produced a dramatic shift in the balance of power between the major political parties, and between state and federal governments. Second, the war produced an unprecedented need for federal govermment revenue.

The demise of free banking, and more broadly of the system of decentralized, state-regulated provision of currency, was caused less by any problems this system may have experienced than by the outbreak of the U.S. Civil War. This extraordinary political event created a pair of peculiar circumstances which helped determine the future

in 1860 , of a single year of 2 percent inflation. The estimates provided by Rolnick and Weber are slightly higher (see their 1983 paper, p. 1089). Cagan (1963), by contrast, repotts with apparent endorsement an estimate by Jay Cooke that the losses were $\$ 50$ million per year. Cagan's use of this estimate in his influential article served to reinforce the conventional view that free banking was a national disaster.

120See Rockoff (1975) and Rolnick and Weber $(1982,1983,1984,1985,1988)$.

${ }^{121}$ See Hammond (1963), p. 14, Temin (1969), p. 50, and

Rockoff (1975), pp. 23-25.

122Rockof (1975), pp. 2-4 
evolution of the U.S. currency and banking system. The first was that it gave the Republican party, the political successor of the old Whig party, almost complete control over the federal government. The majority of the Democratic congressmen and senators were southerners who abandoned their seats and defected to the Confederacy at the outbreak of hostilities. Since the Republicans had inherited from the Whigs a preference for monetary and financial centralization, while the Democrats remained the party of decentralization, the defection of the Democrats greatly increased the prospects for centralizing change in the monetary system.

The second determining circumstance was the federal government's need for enormous new sources of revenue. Though taxes played some role in Civil War finance, particularly in the war's later years, it was clear almost from the beginning that the bulk of the expenditure burden would be met by borrowing. ${ }^{123}$ As the war's cost mounted, however, the federal government began to experience difficulty obtaining the sums required on the open securities market, and turned for assistance to the large Eastern banks. ${ }^{124}$ Unfortunately, the sum required by the government far exceeded the banks' aggregate specie holdings; when the specie borrowed by the government failed for various reason to return to the banks as rapidly as they had anticipated, they were forced to suspend specie payments. ${ }^{125}$ The suspension seemed to close off the possibility of further bank loans, leaving the federal government desperate for new sources of funds and for new ${ }^{*}$, dys to increase the demand for its debt.

One way in which the government might "borrow" was by issuing paper currency. Early in 1862 , at the urging of Secretary of the Treasury Salmon
P. Chase, Congress passed the first Legal Tender Act. The Act authorized the Treasury Department to issue $\$ 300$ million in paper currency. ${ }^{126}$ This currency was not convertible in specie, nor redeemable in specie at any fixed future date; it was, however, made legal tender in payment of public and private debts. ${ }^{127}$ Later in the war, considerable additional quantities of these greenbacks were issued.

The Legal Tender Acts marked the first time in (post-revolutionary) U.S. history that the federal government had issued fiat currency-currency which was entirely irredeemable, and was legal tender for private debts. The Constitution did not give the federal government any explicit right to issue paper currency (fiat or otherwise), or to make paper currency legal tender; indeed, it contained language which was widely interpreted as implicitly denying the government these rights. ${ }^{128}$ This made the legality of the Acts seem very doubtful. In the event, however, no attempt to challenge them managed to reach the Supreme Court until several years after the Civil War had ended. There ensued one of the more bizarre episodes in U.S. monetary history. Chase, who was now Chief Justice, voted with the court majority to strike down legislation whose form he had approved, and whose passage he had recommended, when he was Secretary of the Treasury! The greenbacks were saved when Congress, which remained dominated by the Republicans, voted to increase the number of Supreme Court justices by two; President Grant acted quickly to fill the resulting vacancies with judges who supported the Acts' constitutionality. The enlarged court voted 5-4, with Chase dissenting, to uphold the Acts. ${ }^{229}$ This decision set a precedent that was later used to justify further steps on the part of the federal government to regulate or control the currency

ingly, as the "Resumption Act." [The history and provisions of the Resumption Act are summarized by Friedman and Schwartz (1963), pp. 44-50. See also Timberlake (1978), chapter 8.]

128For discussions of the constitutionality of legal tender federal currency, see Breckinridge (1903), pp. 1 44-37, Mitchell (1903), pp. 51-55, Hurst (1970), pp. 182-86, Christainsen (1988), Timberlake (1989). (1991), chapters 8-10.

129 See Breckinridge (1903), pp. 127-137, Friedman and Schwartz (1963), pp. 46-47, Mitchel (1903), pp. 71-74, and Timberlake (1989), (1991), chapter 9 .

126The provisions of the first and the wo subsequent Legal Tender Act(s) are summarized by Mitchell (1903), pp. 44-118.

$\{27$ In 1875,10 years after the end of the war, Congress enacted legisfation making the greenbacks convertible in specie, according to the prewar definition of the doltar, beginning in 1879. This legislation became known, somewhat mislead- 
system-notably, the creation of the Federal Reserve System.

The greenbacks marked a change in the U.S. currency system which went beyond government issuance of currency. As has already been noted, the fiscal crisis of late 1861 caused the private banking system to suspend specie payments. On earlier occasions when there had been a national or regional suspension, most of the surviving banks had refused to redeem their notes in any way until they could resume redeeming them in specie on demand. The fact that the greenbacks were legal tender, however, gave bank debtors the legal right to use them to repay their debts. Since greenbacks began trading at substantial discounts shortly after they were first issued, moreover, debtors hastened to take advantage of this opportunity. The banks consequently felt entitled, and indeed compelled, to redeem their notes in greenbacks. ${ }^{130}$ Thereafter, the banking system redeemed its notes and deposits almost exclusively in legal tender paper currency, regardless of whether it was convertible in specie. This ensured that goods and assets would be priced in legal tender paper-in other words, that government currency would replace specie as the nation's unit of account.

Because neither Congress nor the Administration was willing to risk a repetition of the Revolutionary hyperinflation, greenbacks could be used to finance at most a small portion of the wartime deficit ${ }^{131}$ The balance of the deficit had to be financed by the issuance of conventional, interestbearing debt. ${ }^{132}$ Secretary Chase responded to this situation by developing a strategy for monetary reform which promised to simultaneously achieve both currency centralization and debt demand enhancement. This program, which was ultimately embodied in the National Banking Act, called for the creation of a "National Banking System" (NBS)-a system of private, federally chartered banks which would be nationally regulated analogues of the state-chartered "free banks." The Act imposed reserve, capital, convertibility and other requirements that were generally similar to those imposed on the free banks. These requirements were to be administered, and the national banks regulated, by a new federal agency called the Office of the Comptroller of the Currency. ${ }^{133}$ For the first time in U.S. history, the federal government had moved to create a system of private banks (rather than a single, centrally administered private bank) under its direct regulatory control.

From the perspective of the currency system, the key features of the National Bank Act involved the notes the national banks were to issue. These notes were to be printed by the Treasury Department and issued to the banks, rather than printed by the banks directly; they were to look entirely uniform, except for an indication of the identity of the issuer. In order to obtain a given value of bank notes, a national bank had to deposit U.S. government securities of essentially equal value (state government securities would not do) with the Comptroller of the Currency. Thus, national bank notes were to be 100 percent backed by U.S. government securities.

The requirement that the notes be backed by federal government securities was designed to create a "captive" demand for federal debt on the part of banks of issue. Since notes were the principal liabilities of contemporary banks, and since the framers of the Act evidently expected most of the state banks to apply for federal charters, there was every reason to expect that the Act would force the banking system to purchase Treasury securities in large quantities. This, it was hoped, would materially ease the federal government's borrowing problems. ${ }^{134}$

Congress, anticipating heavy demand for national bank notes, included provisions in the Act establishing a maximum quantity which could be issued and allocating this quantity across the various regions. ${ }^{13}$ Contrary to expectation, however, during the year or so after the Act was passed the number of charter applications was small, and the volume of U.S. bonds deposited as note backing was far lower than anticipated. Congress

iso See Mtchell (1903), pp. 144-49.

131 the limited financial resources of the southern states made it difficult for the Confederate govemment to borrow large sums. As a result, it was forced to cover a very substantial fraction of its deficit through currency creation. This strategy ultimately produced a hyperinflation. See Lerner (1956), and Timberlake (1978), pp. $102-03$.

132 Mitchell (1903), pp. 119*31, discusses the reasons the federal government issued no greenbacks from 1863 to the end of the Civil Wat.

133 For he history and provisions of the National Banking Act, see Redich (1951), pp. 99-113 and Hammond (1970), chapters $10-11$.

134Discussions of the budgetary motivations for the Nationat Banking Act can be found in Hammond (1957), p. 725, (1970), pp. 135-36, 286-95, and Mitchell (1903), pp. 37 , $44-45,103,109$.

¿35These provisions are summarized by Pedich (1951), p, 118 
responded by amending the Act to impose a punitive tax on state bank notes-a tax rate so high (10 percent) that it made note issue by state banks entirely unprofitable. ${ }^{136}$ This decision eliminated state bank notes from circulation, and marked the final demise of state currency systems.

Of course, a system under which any currency that was not issued directly by the federal govern. ment was printed by the federal government, fully backed by U.S. Treasury securities, and issued in quantities and locations closely regulated by the government, might be said to have differed very little from a system under which the federal government directly issued all paper currency. ${ }^{137}$ Indeed, it could be argued that the only really significant differences between the NBS and a direct note issue system were that under the NBS, the government (1) had little short-run influence over the total quantity of notes (which indeed proved relatively unresponsive to short-run influences of any kind), and (2) assigned the responsibility for clearing the notes (and thus for ensuring their convertibility in specie) to the issuing banks. When 50 years of experience with the system seemed to suggest that these features were serious liabilities, the federal government used the broad monetary powers it had acquired during the Civil War to establish a system of direct issue-the Federal Reserve System.

\section{CONCUUDING REMARKS}

The changes in the U.S. currency system that resulted from the Legal Tender and National Banking acts stand, along with the monetary clauses of the U.S. Constitution, as classic examples of cases in which the basic structure of the system was strongly influenced by extraordinary political events with largely non-economic (or at least, nonmonetaryl causes. If, as we have seen, the American colonies could have obtained their independence from Great Britain without fighting a long, expensive and divisive revolutionary war, the monetary history of the next 90 years might have been very different: historical evidence suggests that the states might have retained the right to issue their own currencies, and that these currencies might not have been convertible in specie. Subsequently, if the American states could have resolved their sectional disputes without fighting a long, expensive and divisive civil war, the monetary history of the ensuing 50 years might also have been very different: historical evidence suggests that the states might have retained the right to charter banks of issue, and that the federal government's role in the U.S. currency system might have remained relatively limited.

It should also be remembered that the federal government chartered the second United States Bank in response to financial dislocations associated with the War of $1812 .{ }^{138}$ In the absence of Second Bank opposition, the inconvertible banking systems that arose in the western and southern states after the Panic of 1819 might have survived and become entrenched; without a Second Bank for the Jacksonians to fight, the "hard money" principles of the Free Banking Era might never have become popular. Here again a sequence of essentially political disputes played a key role in dictating the evolution of U.S. currency arrangements. ${ }^{139}$

\section{Currency System Evolution: An Alternafive View}

As we have seen, U.S. monetary history has been punctuated by a sequence of rather abrupt transitions from one currency system to another with very different features. These transitions are often interpreted as part of a process of Darwinian advancement-a process, that is, through which old and relatively inefficient systems were replaced by new and more efficient successors. The modern currency system emerged out of this process as the most efficient system yet devised.

While this historical interpretation certainly sounds plausible, it is one that we should accept or reject on the basis of evidence concerning the relative efficiency of past and present currency systems. Unfortunately, the prestige of Darwinism

736 See Friedman and Schwartz (1963), pp. 18-19, Hammond

(1957), pp. 732-34, and Redich (1951), p. 113.

Givil War suspension also might have led to the development

${ }^{13}$ This point is made by Friedman and Schwartz (1963), p. 21. of a currency system based on inconvertible bank notes

138 See note 89 above.

139Redlich (1951) comments that had Secretary Chase

promoted the National Banking Act less vigorousiy, the early (p. 95). 
has become so great that economists tend to reverse the logical process by using the various systems' orders in the historical sequence as the basis for efficiency comparisons. (If only the fittest systems survive, then the systems that survived at each stage must have been the fittest.) The disappearance of older systems is regarded as compelling evidence that they were less efficient than their successors.

The claim that the currency system, if left to itself, tends to progress (slowly) in the direction of greater efficiency is not disputed in this article; indeed, several examples of this sort of progression have been presented above. What the article has argued is that the U.S. currency system has not been left to itself, and that its evolution has been anything but an orderly and inevitable progression toward economic efficiency. Instead, it has been dominated by political decisions that were largely uninfluenced by efficiency considerations. Many of these decisions were made in response to political pressures of a particularly urgent sort-pressures growing out of the U.S. government's (and earlier, the British and/or colonial governments') involvement in prolonged and expensive wars.

It is, of course, possible that we have been fortunate, and that the political process has given us a currency system that is very efficient, or at least more efficient than the historical alternatives. It is also possible that we have not been quite so fortunate; the question is a complex one, and cannot be answered here. This article is content to point out that the modern currency system has not developed because of any clear advantage in efficiency. The possibility that history provides attractive alternatives cannot be ruled out, and the question of which system is best remains both open and interesting.

\section{REFERENCES}

Arnold, Samuel G. History of the State of Rhode Island and Providence Plantations, vols. I and II, (D. Appleton, 1878).

Bancroft, George. "Bank of the United States," North American Review (January 1831), pp. 21-64.

Bates, Frank Greene. 'Rhode Island and the Formation of the Union;" Columbia University Studies in History, Economics and Public Law, vol. X, no. 2 (The MacMillan Company, 1898).

Berry, Thomas S. Western Prices Before 1861 (Harvard University Press, 1943).

Billias, George A. "The Massachusetts Land Bankers of 1740," University of Maine Studies, Second series, Number 74 (Maine University Press, 1959).
Breckintidge, S.P. Legal Tender: A Study in English and American Monetary History (University of Chicago Press, 1903).

Brock, Leslie V. The Currency of the American Colonies 1700-1764 (Arno Press, 1975).

Bullock, Charles J. Essays on the Monetary History of the United States (The MacMillan Company, 1900).

Cable, John R. "The Bank of the State of Missourt," Studies in History, Economics and Public Law, vol. 102 (Columbia University Press, 1923).

Cagan, Phillip. "The First Fiffy Years of the National Banking System-An Historical Appraisal," in Deane Carson, ed., Banking and Monefary Studies (Richard D. Irwin Inc., 1963)

Calomiris, Charles W. "Institutiona! Failure, Monetary Sçarcity, and the Depreciation of the Continental," Journal of Economic History (March 1988), pp. 47-68.

Calomiris, Charles W., and Charles M. Kahn. "The Role of Demandable Debt in Structuring Optimal Banking Arrangements;" American Economic Review (June 1991), pp. 497-513

Carothers, Neil. Fractional Money (Augustus M. Kelley, 1930), (reprinted 1967).

Catterall, Ralph C. H. The Second Bank of the United States (University of Chicago Press, 1902).

Checkland, S.G. Scottish Banking: A History, 7695-1973 (Glasgow: Collins, 1975).

Christainsen, Gregory B. "Fiat Money and the Constitution: A Historical Review," in Thomas D. Willett, ed., Political Business Cycles (Duke University Press, 1988).

Clapham, Sir John. The Bank of England, A History, vols, I and II (Cambridge University Press, 1944), (reprinted 1958)

Clough, Shepard B. and Charles W. Cole. Economic History of Europe (Heath, 1941).

Cole, Arthur $\mathrm{H}$. Wholesale Commodity Prices in the United States, 1700-1861 (Harvard University Press, 1938).

Davis, Andrew McFarland. "Currency and Banking in the Province of Massachusetts-Bay," American Economics Association Publications, Third series, Part l: "Currency," Volume I, Number 4, December 1900, Part ll: "Banking," Volume Il, Number 2, May 1901 (The Macmillan Company).

Dewey, Davis R. State Banking before the Civjl War, National Monetary Commission, (U.S. Government Printing Office, 1910).

Dorfman, Joseph. The Economic Mind in American Civilization, 7606-1865, vols. I and II (London: George G. Harrap \& Company LTD., 1947).

Dowd, Kevin. "Option Clauses and the Stability of a Laissez Faire Monetary System," Journal of Financial Services Research (December 1988), pp. 319-33.

Dowrie, George W. "The Development of Banking in llinois, 1817-1863," Studies in the Social Sciences, vol. XI, no. 4 (University of llinois Press, December 1913).

Dwyer, Gerald P., and R. Alton Gilbert. "Bank Runs and Private Remedies," this Review (May/June 1989), pp. 43-61.

Ennst, Joseph A. Money and Politics in America, 1755-1775 (The University of North Carolina Press, 1973).

Felt, Joseph B. An Historical Account of Massachusetts Cur. rency (Burt Franklin, 1839).

Fenstermaker, J. Van. The Development of American Commercial Banking: 1782-1837 (Kent State University Press, 1965a).

"The Statistics of American Commercial Banking, 1782-1818," Journal of Economic History (1965b), pp. 400-13. 
Ferguson, E. James. "Currency Finance: An interpretation of Colonial Monetary Pracices," William and Mary Quarterly, 3 rd series, vol. X (1953), pp. 153 80 .

The Power of the Purse (University of North Carol:riaPress, 1961).

Feavearyear, Sir Albert. The Pound Sterling: A History of English Money (Oxford at the Clarendon Press, 1963).

Flanagan, Beecher. "A History of State Banking in North Carolina to 1866;" Doctoral dissertation, George Peabody College for Teachers, 1935.

Fraas, Arthur. "The Second Bank of the United States: An Instrument for an Interregional Monetary Union" Journal of Economic History (June 1974), pp. 447-67.

Franklin, Benjamin, Essays on General Politics, Commerce and Political Economy, Volume II, Part II of Jared Sparks, ed., The Works of Benjamin Franklin (Augustus M. Kelley, 1971).

Friedman, Milton. A Program for Monetary Stability (Fordham University Press, 1960).

Friedman, Miton, and Anna J. Schwartz. A Monetary History of the United States: 1867-1960 (Princeton University Press, 1963).

Gallatin, Albert. The Writings of Abert Gallatin, Heriry Adams, ed., vol. III (u. B. Lippincott \& Company, 1879).

Gouge, William M. A Short History of Paper-Money and Banking in the United States (T. W. Ustick, 1833).

Gould, Stephen Jay. Wonderful Life: The Burgess Shale and the Nature of History (W. W. Norton \& Company, 1989).

Govan, Thomas P. "Banking and the Credit System in Georgia, 1810-1860" Doctoral dissertation, Vanderbilt University, 1937 (Arno Press, 1978).

Greene, Jack P., and Richard M. Jellison. "The Currency Act of 764 in Imperial-Colonial Relations, 1764-1766," Willam and Mary Quarterly, Third series, Volume XVIII (1961), pp. 485-518.

Hammond, Bray. "Long and Short term Credit in Early American Banking." Quarterly Joumal of Economics, vol, XLIX (1934), pp. 79-103.

Banks and Politics in America from the Revolution to the Civil War (Princeton University Press, 1957).

"Banking Before the Civil War," in Deane Carson, ed. Banking and Monetary Studies (Richard D. Irwin Inc., 1963), pp. 1-14.

Sovereignty and an Empty Purse: Banks and Politics in the Civil War (Princeton University Press, 1970).

Heath, Milton Sidney. Constructive Liberalism: The Role of the State in Economic Development in Georgia to 1860 (Harvard University Press, 1954).

Hepburn, A. Barton. A History of Currency in the United States (Augustus M. Kelley, 1903), (reprinted 1967).

Holder, Brantson B. "The Three Banks of the state of North Carolina: 1810-1872," Doctoral dissertation, University of North Carolina, 1937.

Holdsworth, John T, and Davis R. Dewey. The First and Second Banks of the United States (U.S. Government Printing Office, 1910).

Horsefield, J. Keith. British Monetary Experiments, 1650-1710 (Harvard University Press, 1960)

Hoyt, Elizabeth S. "Reactions in North Carolina to Jacksoris Banking Policy, 1829-1832," North Carolina Historical Review (1948), pp. 167-78.

Huntington, A. T., and Robert J. Mawhinney. Laws of the United States Concerning Money, Banking, and Loans, 17778-1909, National Monetary Commission (U.S. Government Printing Office, 1910).
Hursi, James W. A Legal History of Money in the United States 1774-1970 (University of Nebraska Press, 1973).

Kemmerer, Donald L. "The Colonial Loan-Office System in New Jersey," Journal of Political Economy (December 1939), pp. 867-74.

King, Robert G. "On the Economics of Private Money," Journal of Monetary Economics (July 1983), pp. 127-58.

Klein, Benjamin. "The Competitive Supply of Money," Journal of Money, Credit and Banking (November 1974), pp. 423-53.

Knox, John Jay. A History of Banking in the United States (Rhodes \& Company, 1903).

Lerner, Eugene M. "Inflation in the Confederacy, 1861-1865," in Milton Friedman, ed., Studies in the Quantity Theory of Money (University of Chicago Press, 1956).

Libby, Orin G. The Geographical Distribution of the Vote of the Thirteen States on the Federal Constitution 1787-8 (University of Wisconsin Press, June 1894).

Macaulay, Thomas B. A History of England trom the AC-

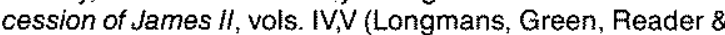
Dyer, 1877 )

Macon, Hershal L. "A Fiscal History of North Carolina, 1776-1860," Doctoral dissertation, University of North Carolina, 1932

Metz, William D. "Politics and Finance in Massachusetts, 1713-1741:" Doctoral dissertation, University of Wisconsin, 1945.

Mitchell, Wesley C. A History of the Greenbacks (University of Chicago Press, 1903).

Nettels, Curtis P. The Emergence of a National Economy, 1775-1815 (M. E. Sharpe, Inc., 1962)

The Money Supply of the American Colonies Before 1720 (University of Wisconsin Press, 1934).

Nevins, Allan. The American States During and After the Revolution: 1775-1789 (Augustus M. Kelley, 1924).

North American Review. "Bank of the United States" (April 1831), pp. 524-63.

Phillips, Henry Ji. Historical Sketches of the Paper Currency of the American Colonies (W. E. Woodward, 1865)

Redilich, Fritz. The Molding of American Banking Men and Ideas, Parts / and /I (Johnson Reprint Corporation, 1951)

Rockoff, Hugh." The Free Banking Era: A Re-examination," Journal of Money, Credit and Banking (May 1974), pp. 141-67.

The Free Banking Era: A Re-examination (Amo Press, 1975)

"Institutional Requirements for Stable Free Banking Regime," Cato Journal (Fall 1986), pp. 617-34.

Rolnick, Arthur J., and Warren E. Weber. "Free Banking, Wildcat Banking, and Shinplasters." Federal Reserve Bank of Minneapolis Quarterly Review (Fall 1982), pp. 10-19.

"New Evidence on the Free Banking Era" American Economic Review (December 1983), pp. 1080-91.

"The Causes of Free Bank Fatures: A Detailed Ex amination," Journal of Monetary Economics (November 1984), pp. 267-91.

"Banking Instability and Regulation in the U.S. Free Banking Era," Federal Reserve Bank of Minneapolis Quarterly Review (Summer 1985), pp. 2-9

"Explaining the Demand for Free Bank Notes", Journal of Monetary Economics (January 1988), pp. 4771.

"Gresham's Law or Gresham's Fallacy?" Journal of Political Economy (February 1986), pp. 18599. 
Rothbard, Murray. The Panic of 1819 (Columbia University Press, 1962).

Russell, Steven. "Some Implications of the Colonial Currency Experience," Working paper, April 1988.

"'Free Banking' as Inconvertible Banking: North Carolina, 1819 1828," Working paper, September 1989a.

"Inconvertible Banking in the Early Nineteenth Century United States: A Legal Restrictions Approach", Working paper, October 1989 b.

"The Pricing of North Carolina Bank Notes, 1818-1827: An Empirical Investigation," Working paper, May $1989 \mathrm{c}$.

Santoni, G.J. "A Private Central Bank: Some Olde English Lessons," this Review (April 1984), pp. 12-22.

Schlesinger, Arthur M. Jr. The Age of Jackson (Little, Brown and Company, 1953).

Schweitzer, Mary M. "State-Issued Currency and the Ratification of the U.S. Constitution," Journal of Economic History (June 1989), pp. 311-22.

Scott, William Robert. The Constitution and Finance of English, Scottish and Irish Joint-Stock Companies to 1720 , Three volumes (Cambeidge: The University Press, 1910 12).

Smith, Adam. The Wealth of Nations, Edited and introduced by Edwin Cannan (Random House, Inc., 1937, originaly published in 1776 .)

Smith, Bruce D. "Money and Inflation in Colonial Massachusetts," Federal Reserve Bank of Minneapolis Quarterly Review (Winter 1984), pp. 1-14.

"American Colonial Monetary Regimes: The Failure of the Quantity Theory and Some Evidence in Favour of an Alternative View," Canadian Journal of Economics (August 1985a), pp. 531-65.

"Some Colonial Evidence on Two Theories of Money: Maryland and the Carolinas", Joumal of Political Economy (December 1985b). pp. 1178-211.

Smith. Walter B. Economic Aspects of the Second Bank of the United States (Harvard University Press, 1953).

Smith, Walter B, and Arthur H. Cole. Fluctuations in American Business, 1790-1860 (Harvard University Press, 1935).

Sumner, Wiltiam G. A History of Banking in All the Leading Nations, Volume I (The Journal of Commerce and Commercial Butletin, 1896)
Sylla, Richard, John B. Legler, and John J. Wallis. "Banks and State Public Finance in the New Republic: The United States: 1790-1860," Journal of Economic History (June 1987). pp. $391-403$.

Taus, Esther Rogoft. Central Banking Functions of the United States Treasury, 1789 1941 (Columbia University Press, 1943).

Taylor, Robert $\mathrm{J}$. Western Massachusetts in the Revolution (Brown University Press, 1954)

Temin, Peter. The Jacksonian Economy (W. W. Norton \& Company, Inc., 1969).

Thayer, Theodore. "The Land-Bank System in the American Colonies," Journal of Economic History (Spring 1953), pp 145-59.

Timberlake, Richard H. Jr. "The Specie Circular and Distribution of the Surplus;" Journal of Political Economy (April 1960), pp. 109-17.

"Denominational Factors in Nineteenth-Century Currency Experience," Journal of Economic History (December 1974), pp. $835-50$

The Origins of Central Banking in the United States (Harvard University Press, 1978)

"The Significance of Unaccounted Currencies," Journal of Economic History (December 1981), pp. 853-66.

. "The Government's License to Create Money;" Cato Journal (Fall 1989), pp. 301-21.

Gold, Greenbacks, and the Consfitution (George Edward Durrell Foundation, 1991).

U.S. Constitution.

Viner, Jacob. Studies in the Theory of International Trade (Harper \& Brothers, 1937).

Waltace, Neil. "A Legal Restrictions Theory of the Demand for 'Money' and the Role of Monetary Policy.' Federal Reserve Bark of Minneapolis Quarterly Review (Winter 1983), pp. 1-7.

White, Lawrence H. Free Banking in Britain: Theory, Ex. perience, and Debate 1800-1845 (Cambridge University Press, 1984)

"Accounting for Non-interest-Bearing Currency: A Critique of the Legal Restrictions Theory of Money," Journal of Money, Credit and Banking (November 1987), pp. 448-56.

West, Robert Craig. "Money in the Colonial American Economy." Economic Inquiry (January 1978), pp. 1-15.

Wilburn, Jean Alexander. Biddle's Bank: The Crucial Vears (Columbia University Press, 1967) 